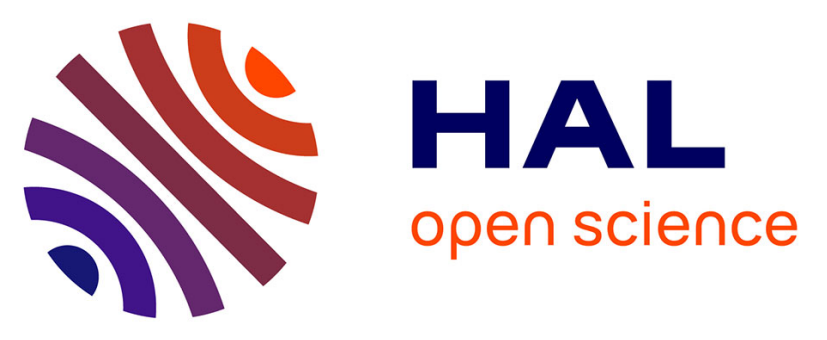

\title{
Mono- and Poly-unsaturated Phosphatidic Acid Regulate Distinct Steps of Regulated Exocytosis in Neuroendocrine Cells
}

Émeline Tanguy, Pierre Costé de Bagneaux, Nawal Kassas, Mohamed-Raafet Ammar, Qili Wang, Anne-Marie Haeberlé, Juliette Raherindratsara, Laëtitia Fouillen, Pierre-Yves Renard, Maïté Montero-Hadjadje, et al.

\section{To cite this version:}

Émeline Tanguy, Pierre Costé de Bagneaux, Nawal Kassas, Mohamed-Raafet Ammar, Qili Wang, et al.. Mono- and Poly-unsaturated Phosphatidic Acid Regulate Distinct Steps of Regulated Exocytosis in Neuroendocrine Cells. Cell Reports, 2020, 32 (7), pp.108026. 10.1016/j.celrep.2020.108026 . hal02922310

\author{
HAL Id: hal-02922310 \\ https://hal.science/hal-02922310
}

Submitted on 12 Nov 2020

HAL is a multi-disciplinary open access archive for the deposit and dissemination of scientific research documents, whether they are published or not. The documents may come from teaching and research institutions in France or abroad, or from public or private research centers.
L'archive ouverte pluridisciplinaire HAL, est destinée au dépôt et à la diffusion de documents scientifiques de niveau recherche, publiés ou non, émanant des établissements d'enseignement et de recherche français ou étrangers, des laboratoires publics ou privés. 


\section{Cell Reports}

\section{Mono- and Poly-unsaturated Phosphatidic Acid Regulate Distinct Steps of Regulated Exocytosis in Neuroendocrine Cells}

\section{Graphical Abstract}

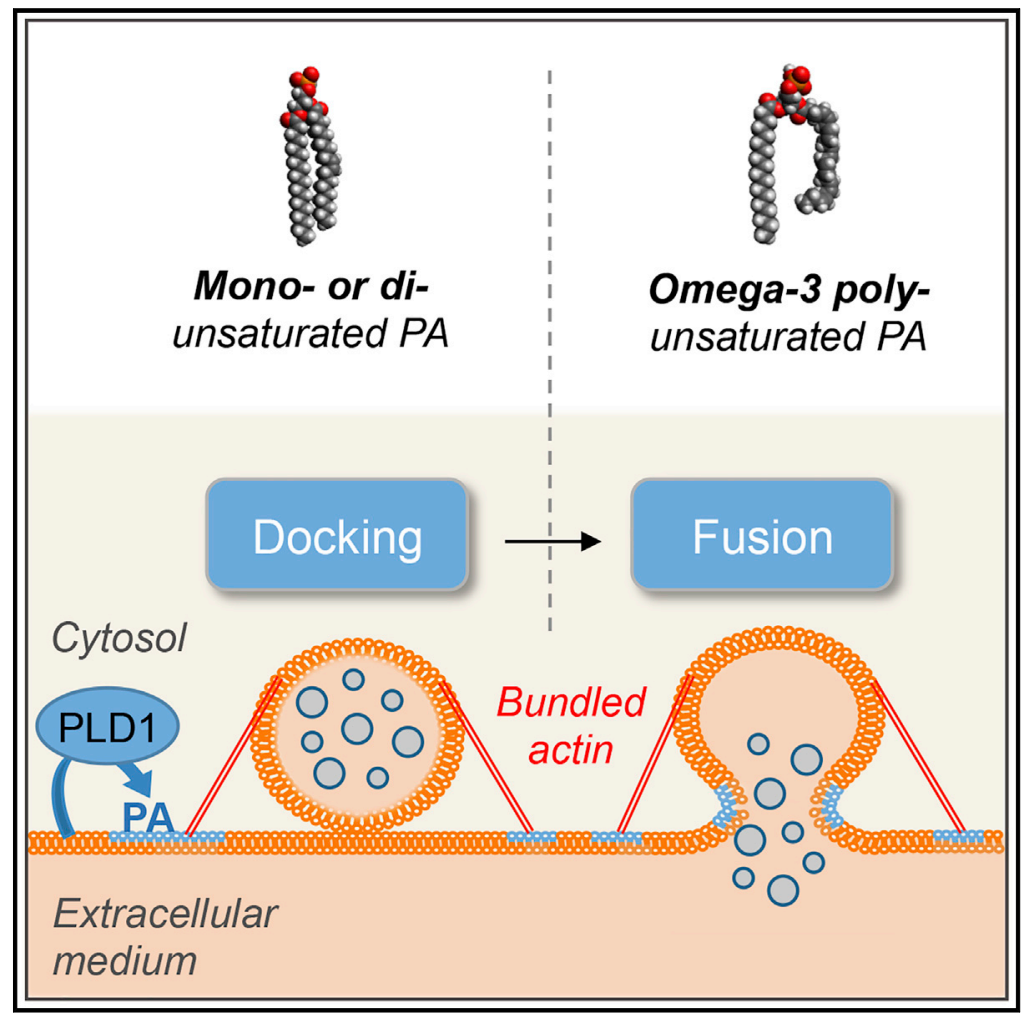

Highlights

- PA produced by PLD1 is involved in distinct steps of neuroendocrine exocytosis

- Secretagogue-evoked stimulation leads to the production of several PA species

- Mono-unsaturated PA regulates the number of exocytotic events

- Poly-unsaturated PA regulates fusion pore stability and expansion

\section{Authors}

Emeline Tanguy,

Pierre Costé de Bagneaux, Nawal Kassas, ..., Stéphane Gasman, Marie-France Bader, Nicolas Vitale

\section{Correspondence}

vitalen@unistra.fr

\section{In Brief}

Tanguy et al. report that monounsaturated and poly-unsaturated phosphatidic acid (PA) regulate steps of the neurosecretory pathway. Polyunsaturated PA controls the initial fusionpore lifetime and its expansion before full vesicular fusion, suggesting that it may contribute to the beneficial cognitive function of poly-unsaturated fatty acids by optimizing neurotransmitter release. 


\title{
Mono- and Poly-unsaturated Phosphatidic Acid Regulate Distinct Steps of Regulated Exocytosis in Neuroendocrine Cells
}

\author{
Emeline Tanguy, ${ }^{1}$ Pierre Costé de Bagneaux, ${ }^{1}$ Nawal Kassas, ${ }^{1}$ Mohamed-Raafet Ammar, ${ }^{1}$ Qili Wang, ${ }^{1}$ \\ Anne-Marie Haeberlé, ${ }^{1}$ Juliette Raherindratsara, ${ }^{1}$ Laetitia Fouillen, ${ }^{2}$ Pierre-Yves Renard, ${ }^{3}$ Maité Montero-Hadjadje, ${ }^{4}$ \\ Sylvette Chasserot-Golaz, ${ }^{1}$ Stéphane Ory, ${ }^{1}$ Stéphane Gasman, ${ }^{1}$ Marie-France Bader,${ }^{1}$ and Nicolas Vitale ${ }^{1,5, *}$ \\ ${ }^{1}$ Centre National de la Recherche Scientifique, Université de Strasbourg, Institut des Neurosciences Cellulaires et Intégratives, UPR-3212 \\ 67000 Strasbourg, France \\ 'Laboratoire de Biogénèse Membranaire, UMR-5200 Centre National de la Recherche Scientifique, Plateforme Métabolome, Université de \\ Bordeaux, 33883 Villenave D'Ornon, France \\ ${ }^{3}$ Normandie Université, UNIROUEN, COBRA, UMR 6014 \& FR 3038, INSA Rouen, Centre National de la Recherche Scientifique, 76000 \\ Rouen, France \\ ${ }^{4}$ Normandie Université, UNIROUEN, INSERM, U1239, Laboratoire de Différenciation et Communication Neuronale et Neuroendocrine, \\ Institut de Recherche et d'Innovation Biomédicale de Normandie, 76000 Rouen, France \\ ${ }^{5}$ Lead Contact \\ ${ }^{*}$ Correspondence: vitalen@unistra.fr \\ https://doi.org/10.1016/j.celrep.2020.108026
}

\section{SUMMARY}

Specific forms of fatty acids are well known to have beneficial health effects, but their precise mechanism of action remains elusive. Phosphatidic acid (PA) produced by phospholipase D1 (PLD1) regulates the sequential stages underlying secretory granule exocytosis in neuroendocrine chromaffin cells, as revealed by pharmacological approaches and genetic mouse models. Lipidomic analysis shows that secretory granule and plasma membranes display distinct and specific composition in PA. Secretagogue-evoked stimulation triggers the selective production of several PA species at the plasma membrane near the sites of active exocytosis. Rescue experiments in cells depleted of PLD1 activity reveal that mono-unsaturated PA restores the number of exocytotic events, possibly by contributing to granule docking, whereas poly-unsaturated PA regulates fusion pore stability and expansion. Altogether, this work provides insight into the roles that subspecies of the same phospholipid may play based on their fatty acyl chain composition.

\section{INTRODUCTION}

Phosphatidic acid (PA), the simplest glycerophospholipid naturally occurring in living organisms and a minor component of membranes, is receiving increasing interest because of its potential for multiple biological functions. For example, as a key intermediate metabolite in the synthesis of all membrane glycerophospholipids, PA contributes to membrane biogenesis, thereby playing an important structural role in living cells. PA is also an essential signaling molecule in diverse cellular functions such as cell proliferation and cytoskeletal rearrangement through the recruitment of a range of cytosolic effector proteins to appropriate membrane locations. In addition, because of its structural properties, PA is capable of remodeling and bending membranes when locally concentrated (Pokotylo et al., 2018; Tanguy et al., 2019a; Zegarlińska et al., 2018). In membrane trafficking events, despite receiving little initial attention compared with phosphoinositides, there is now compelling evidence for an essential role for PA. PA has been shown to participate in endocrine and neuroendocrine exocytosis (Bader and Vitale, 2009; Vitale et al., 2001; Waselle et al., 2005), synaptic neurotransmis- sion (Humeau et al., 2001; Raben and Barber, 2017), mast cell degranulation (Choi et al., 2002), secretion from endothelial cells (Disse et al., 2009), phagocytosis (Corrotte et al., 2006; Tanguy et al., 2019b), and autophagy (Holland et al., 2016). However, despite this large implication, the precise function of PA along the secretory pathway remains obscure. The diversity of the PA biosynthetic routes, together with the possible occurrence of many PA species based on the fatty acyl chain composition, opens the possibility for multiple roles in a given cellular function (Tanguy et al., 2019a). For instance, in membrane trafficking, PA might recruit specific proteins and/or facilitate fusion because of higher curvature of PA-enriched membranes. Whether these roles rely on specific PA subspecies remains unknown and unexplored. Given the awareness of the relevance of PA in a growing number of cell functions and human diseases (Di Paolo and Kim, 2011; Nelson and Frohman, 2015; Tanguy et al., 2019a), understanding the significance of the dynamics and roles of the diverse forms of PA is becoming an important research goal.

In neuroendocrine cells, the requirement for PA in calcium-regulated exocytosis is probably one of the best documented (Bader and Vitale, 2009). After initial studies reporting the inhibitory action 
A

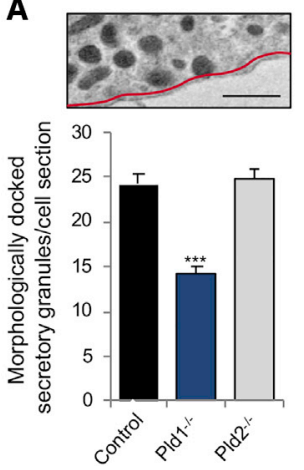

B

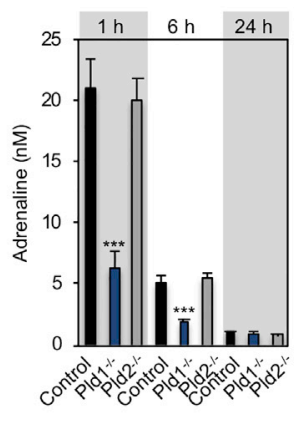

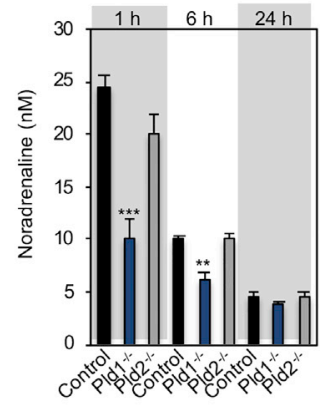

Figure 1. PLD1 Knockout in Mice Affected Secretory Granule Distribution in Adrenal Medullary Chromaffin Cells and Reduced Stress-Induced Catecholamine Release

(A) Representative transmission electron micrograph of an adrenal medulla slice from 3-monthold mice; scale bar, $1 \mu \mathrm{m}$. Morphologically docked secretory granules present in the $50 \mathrm{~nm}$ below the plasma membrane (red line) per cell section were counted in the adrenal medulla of wild-type (control), $\mathrm{Pld}^{-1-}$, and $\mathrm{Pld} 2^{-1-}$ mice $(\mathrm{n}=6$ mice per genotype, from which 50 slices were analyzed per mouse; ${ }^{* \star *} p<0.001$ compared with control).

(B) PLD1 knockout reduced catecholamine secretion in mice. Adrenaline and noradrenaline levels were measured from the blood of newborn wild-type (control), $\mathrm{Pld}^{-1-}$, or $\mathrm{Pld} 2^{-/-}$mice 1, 6, or $24 \mathrm{~h}$ after birth. Data are means $\pm \mathrm{SD}\left(\mathrm{n}>9 ;{ }^{* \star} \mathrm{p}<0.01,{ }^{* *} \mathrm{p}<0.001\right.$ compared with control).

of butanol on exocytosis in different cell models through the inhibition of PA synthesis by phospholipase D (PLD), the first direct molecular evidence supporting the involvement of PA generated by the PLD1 isoform in hormone release was obtained in neuroendocrine chromaffin cells. Overexpression of PLD1, but not PLD2; injection of a dominant-negative PLD1 (Vitale et al., 2001); or PLD1 silencing (Zeniou-Meyer et al., 2007) inhibited catecholamine release, indicating that PLD1 is the major source for PA synthesis during exocytosis in chromaffin cells. Thereafter, the use of a molecular sensor for PA revealed a calcium-stimulated accumulation of PA restricted to the plasma membrane in cells undergoing exocytosis (Zeniou-Meyer et al., 2007). Further studies highlighted the tight regulation of PLD1 activity by several upstream signaling pathways (Bader and Vitale, 2009; Béglé et al., 2009; Momboisse et al., 2009; Vitale et al., 2005; Zeniou-Meyer et al., 2008), revealing a finely tuned production of PA at the granule docking sites in stimulated chromaffin cells. Finally, in line with the selective production of PA at the plasma membrane, capacitance recordings of chromaffin cells silenced for PLD1 indicated that PLD1 controls the population of fusion-competent secretory granules at the plasma membrane (Zeniou-Meyer et al., 2007). Altogether, these experiments revealed the elaborate regulation and functional importance of PLD1-derived PA in exocytosis, but the role and relevance of PA subspecies remained to be explored.

In the present manuscript, we use genetic alteration of PLD1 expression in mice to dissect by amperometry the role of PA in the sequential stages underlying the exocytotic process in chromaffin cells. We identified several PA species formed at the plasma membrane in stimulated neuroendocrine cells. Rescue experiments in cells depleted of PLD1 activity reveal that distinct PA species are implicated in the docking of secretory granules to the plasma membrane and in the lifetime of the initial fusion pore and its dilation for granule content release.

\section{RESULTS}

Impairing PLD1 Expression Affects Exocytosis at Distinct Stages

In bovine chromaffin and in rat PC12 pheochromocytoma cells, both PLD1 and PLD2 isoforms are expressed (Figure S1), but PLD1 is the main contributor of PA synthesis required for cate- cholamine secretion (Vitale et al., 2001; Zeniou-Meyer et al., 2007). Accordingly, and in agreement with previous analysis performed on mouse brain (Oliveira et al., 2010), Pld1 knockout, but not Pld2 knockout (Figure S1), strongly reduced the level of the most abundant PA species detected in the mouse adrenal gland (Figure S2). Interestingly, electron microscopy and morphometric analysis on mouse adrenal gland slices revealed that Pld1 knockout, but not Pld2 knockout, significantly reduced the number of secretory granules visually docked at the plasma membrane in chromaffin cells (Figure 1A). To investigate the physiological significance of PLD1 in catecholamine secretion in vivo, we used Pld knockout mice and measured catecholamine levels in the blood from newborn mice during birth stress, because a dramatic rise in adrenaline and noradrenaline levels has been reported after birth in several mammalian species, including humans (Slotkin and Seidler, 1988). Indeed, in wildtype mice, blood adrenaline and noradrenaline levels were extremely high after birth but rapidly decreased afterward (Figure 1B). Pld1 knockout, but not Pld2 knockout, largely prevented this rise of adrenaline and noradrenaline short after birth (Figure 1B), validating PLD1 as an important player in the regulation of stress-induced catecholamine release.

To gain insight into the role of PLD1-derived PA in neuroendocrine exocytosis, we used cultured chromaffin cells from wildtype, $P l d 1^{-1-}$, and $P l d 2^{-/-}$mice and recorded catecholamine secretion by carbon fiber amperometry to determine the frequency and kinetics of individual exocytotic events (Fathali and Cans, 2018; Mosharov and Sulzer, 2005; Wightman et al., 1991). Figure 2 A shows representative amperometric traces recorded from chromaffin cells stimulated with nicotine. Although Pld2 knockout had no significant effect, Pld1 knockout decreased by nearly $60 \%$ the frequency of the amperometric events corresponding to single-granule fusion (Figure 2A), in good agreement with the apparent reduction of the number of morphologically docked granules seen in the $P l d 1^{-1-}$ adrenal gland (Figure 1A).

Thereafter, the shape of the individual amperometric spikes was analyzed (Fathali and Cans, 2018; Mosharov and Sulzer, 2005; Wightman et al., 1991). Typically, an amperometric spike is marked by a rapid rise corresponding to the quick release of a high concentration of catecholamine through the fusion pore 

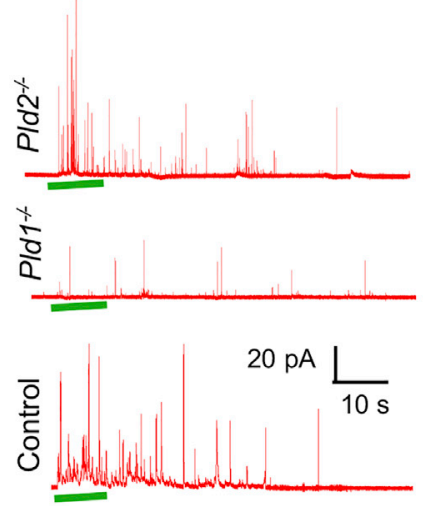

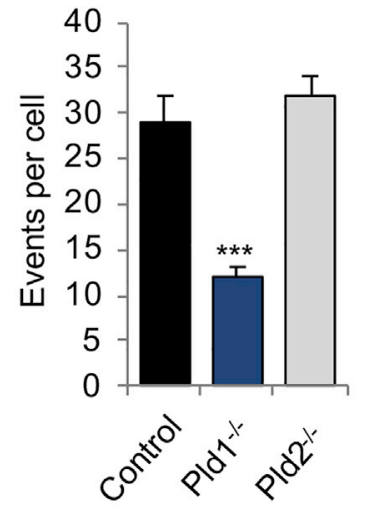

C

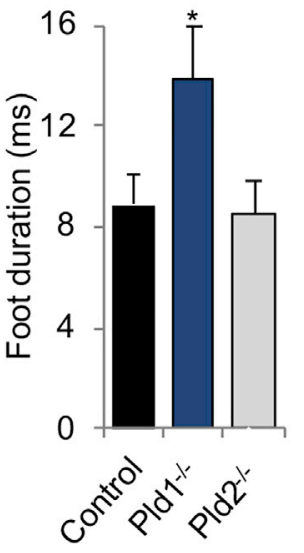

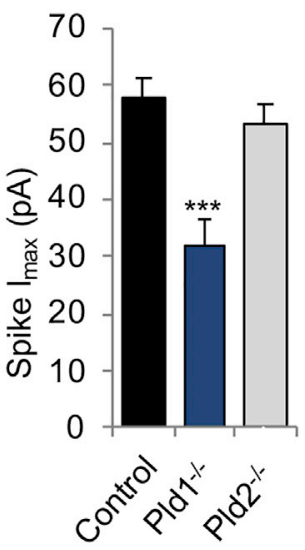

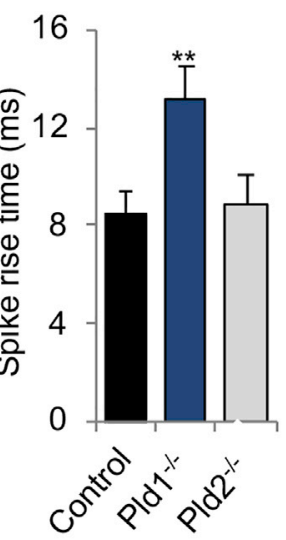

B

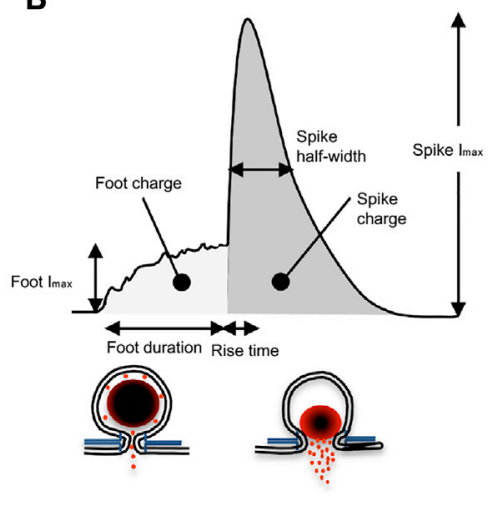

Figure 2. Exocytosis Is Affected at Distinct Stages in Adrenal Chromaffin Cells

(A) Mouse chromaffin cells in culture were stimulated with a local application of $100 \mu \mathrm{M}$ nicotine for $10 \mathrm{~s}$ (green bars), and catecholamine secretion was monitored using carbon fiber amperometry. Typical amperometric recordings obtained from chromaffin cells of wild-type (control), $P I d 1^{-1-}$, or Pld2 ${ }^{-/-}$mice are presented. The histogram corresponds to the total number of amperometric spikes recorded per cell in response to $10 \mathrm{~s}$ stimulation $\left(101<\mathrm{n}\right.$ cells $<127$; ${ }^{\star \star \star} \mathrm{p}<0.001$ compared with control).

(B) Scheme illustrating the parameters of the amperometric spike.

(C) Amperometric spike parameters analyzed in chromaffin cells of wild-type (control), $P / d 1^{-1-}$, and $P / d 2^{-1-}$ mice. PLD1 knockout affected foot duration and three spike parameters, namely, spike rise time, spike half-width, and spike amplitude $\left(I_{\max }\right)$. Data are expressed as means $\pm S D$ ( $n>100$ cells for each condition from four independent cell cultures; ${ }^{\star} \mathrm{p}<0.05,{ }^{* \star} \mathrm{p}<0.01,{ }^{* \star *} \mathrm{p}<0.001$ compared with control).

(D) PLD1 activity is required for CgA secretion. Bovine chromaffin cells in culture were treated with the PLD inhibitors FIPI, CAY93 (C93), CAY94 (C94), or vehicle (C) for $1 \mathrm{~h}$ before stimulation for $10 \mathrm{~min}$ with $59 \mathrm{mM} \mathrm{K}^{+}$. Secretion of $\mathrm{CgA}$ was estimated by western blot quantification of the CgA present in the cell incubation medium from resting $(R)$ and stimulated $(S)$ cells. Data are given as the mean values \pm SD obtained in three experiments performed on cell cultures $\left(n=3 ;{ }^{* *} p<\right.$ 0.01 compared with resting condition).

as it dilates, followed by a slower decay representing the subsequent diffusion of molecules from the release site to the electrode surface (Figure 2B). Analyzing the kinetic parameters from single-current spikes provides dynamic information on fusion pore formation and dilation. The most commonly measured spike characteristics include the spike area (spike charge), the spike maximal height $\left(I_{\text {max }}\right)$, the spike width at half its height (spike half-width), and the spike rise time (Figure 2B). The spike charge is directly related to the total number of catecholamine molecules released from a single granule (Fathali and Cans, 2018; Mosharov and Sulzer, 2005; Wightman et al.,
1991). The values of $I_{\max }$ and half-width have been shown to depend on several factors, including not only the maximal flux of catecholamine but also the dissolution and extrusion of transmitter from the granule content (Borges et al., 1997). The spike rise time directly reflects the kinetics of the fusionpore expansion. Pld1 knockout significantly affected some of these spike parameters, whereas Pld2 knockout had no effect (Figure 2C; Table S1). Although the spike charge was not modified (Table $\mathrm{S} 1)$, the spike rise time was significantly increased in PLD1depleted cells (Figure 2C). Pld $1^{-1-}$ cells also displayed broader spikes with an increased half-width and a reduced $I_{\max }$ 
(Figure 2C). Thus, although the total amount of catecholamine released per granule was not modified (Table S1), the kinetics of the pore dilation and the duration of the exocytotic event were affected by the absence of PLD1.

Many amperometric spikes display a pre-spike feature called a foot that corresponds to the release of catecholamine passing through an initial narrow fusion pore before the pore dilates and releases part or all granule catecholamine content, giving rise to the spike. The amplitude and lifetime of foot features portray information about fusion pore size, dynamics, and stability. Pld $1^{-/-}$chromaffin cells exhibited significantly longer pre-spike foots (Figure $2 \mathrm{C}$ ) but no significant modification in their amplitude and charge (Table S1), suggesting an implication of PLD1 in the duration of the nascent fusion pore before its enlargement for partial or full release of larger protein-based materials contained in the granules. Altogether, these findings indicate that the production of PA by PLD1 controls the number of secretory granules undergoing exocytosis and, at the single-granule level, the duration of the initial fusion pore and its expansion to release the granular content.

Besides containing catecholamine and small molecules like ascorbic acid and ATP releasable through the initial fusion pore, chromaffin granules contain various large proteins, including chromogranins, pro-hormone precursors, enzymes, and proteases, which require the expansion of the fusion pore to be secreted (Estévez-Herrera et al., 2016; Kim et al., 2001). To assess the implication of PLD1-derived PA in fusion pore enlargement, we examined the effect of PLD1 inhibition on secretagogue-evoked chromogranin $A(\mathrm{CgA})$ release. To obtain a reproducible and sufficient amount of $\mathrm{CgA}$ secreted in the cell incubation medium, these experiments were performed on bovine chromaffin cells in which PLD activity was inhibited using the dual PLD1/PLD2 inhibitor FIPI or isoform-specific inhibitors, CAY93 for PLD1 and CAY94 for PLD2 (Scott et al., 2009; Su et al., 2009). Preliminary experiments were performed to assess the effect of these pharmacological inhibitors of PLD on bovine chromaffin cell exocytotic activity estimated by amperometry. Both FIPI and CAY93 modified amperometric spike parameters in a manner similar to that observed in mouse Pld $1^{-1-}$ chromaffin cells (Figure S3). FIPI and CAY93 also inhibited $\mathrm{CgA}$ secretion from bovine chromaffin cells stimulated by high $\mathrm{K}^{+}$, whereas CAY94 had no effect (Figure 2D). Thus, in line with the results obtained by amperometry, these observations confirm that PLD1-produced PA controls not only the number of functional exocytotic release sites but also the expansion of the initial fusion pore for partial or full release of the secretory granule cargo.

\section{Specific PA Species Are Produced at the Plasma} Membrane during Neuroendocrine Cell Exocytosis To characterize the PA composition of secretory granule and plasma membranes under resting and stimulated conditions, we used the PC12 cell line derived from a rat adrenal medulla pheochromocytoma, which enabled us to perform subcellular fractionation on cultured cells and obtain sufficient material for comprehensive lipid analysis (Kassas et al., 2017). PC12 secretory granules and plasma membranes were purified on sucrose density gradients (Vitale et al., 2002). Both granule membrane and plasma membrane contained detectable levels of up to 40 PAspecies (Figure S4). Secretory granules were particularly enriched in poly-unsaturated PA forms, especially PA 40:6 containing docosahexaenoic acid (DHA), a major omega-3 fatty acid (Figure S4). Surprisingly, although the total amount of PA present in the plasma membrane was around $12.5 \pm 0.8 \mathrm{nmol} / \mathrm{mg}$ of protein, the amount of PA found in secretory granule membranes was around $36.3 \pm$ $1.1 \mathrm{nmol} / \mathrm{mg}$ of protein (Figure $3 \mathrm{~A}$ ), and this excess largely resulted from poly-unsaturated PA, including PA 40:6 (Figure S4). PC12 cell stimulation with a depolarizing concentration of $\mathrm{K}^{+}$decreased the total amount of secretory granules by $\sim 25 \%$ but the PA/protein ratio found in the granule membrane was not modified (Figure 3A). In contrast, $\mathrm{K}^{+}$stimulation increased the level of PA found in the plasma membrane by more than 6-fold compared with resting cells, to reach $76.5 \pm 1.2 \mathrm{nmol} / \mathrm{mg}$ of protein (Figure 3A). This increase of PA in the plasma membrane upon cell stimulation largely relied on PA containing long-chain mono-unsaturated and di-unsaturated fatty acids (PA 36:1, PA 38:1, and PA 38:2), although several poly-unsaturated PA species, including omega-3-containing forms, were also found in larger amounts (Figure 3B; Figure S5). Based on our previous findings showing the activation of PLD1 at the plasma membrane in secretagogue-stimulated cells (ZeniouMeyer et al., 2007), and taking into account that secretory granule membranes are enriched in poly-unsaturated PA, we propose that the increase of PA seen here in the plasma membrane following cell stimulation results from PLD1 activation, rather than granule membrane incorporation.

Thereafter, we examined the distribution within the plasma membrane of the PA synthesized in stimulated cells using bovine chromaffin cells expressing the PA sensors Spo20p-GFP and PDE4A1-GFP (Kassas et al., 2017). Both PA binding domains of Spo20p and PDE4A1 preferentially bind PA over other lipids, but they distinguish the membrane environment of PA. Spo20p is a PA sensor particularly suited to detect PA in endosomal and plasma membranes, whereas PDE4A1 preferentially binds PA found in the Golgi membrane (Carmon et al., 2020; Kassas et al., 2012, 2017). As seen by confocal microscopy, in nicotineand high $\mathrm{K}^{+}$-stimulated chromaffin cells, Spo20p-GFP was partially recruited to the cell periphery in line with the increase of $\mathrm{PA}$ in the plasma membrane upon cell stimulation (Figure S6A), whereas a Spo20p-GFP mutant with reduced affinity for PA remained in the nucleus (Figure S6B). Using immunogold electron microscopy with anti-GFP antibodies, we studied the association of Spo20p-GFP and PDE4A1-GFP on plasma membrane sheets prepared from resting or $\mathrm{K}^{+}$-stimulated chromaffin cells (Gabel et al., 2015). Plasma membrane sheets prepared from resting chromaffin cells expressing Spo20p-GFP displayed only few gold particles, which were observed in most cases near docked granules (Figure 4A). Similarly, gold particles were rarely found on plasma membrane sheets obtained from cells expressing PDE4A1-GFP (Figure 4A). Cell stimulation increased the population of docked secretory granules and the number of gold particles at the plasma membrane in cells expressing Spo20p-GFP, but not in cells expressing PDE4A1-GFP (Figure 4A). Numerical analysis of particle distribution relative to granule position indicated that nearly one-third of the Spo20p-GFP PA sensor was detected on or below docked secretory granules, another third was concentrated in a $50 \mathrm{~nm}$-zone from the edge of the granules, and the 
A

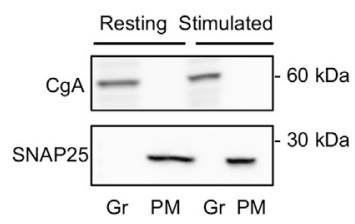

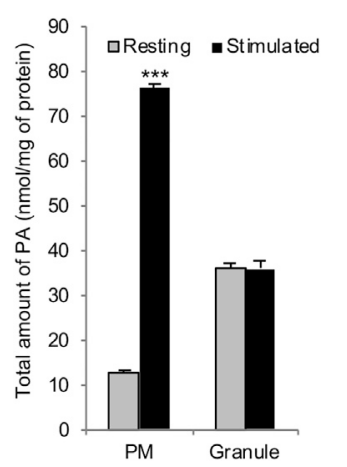

B

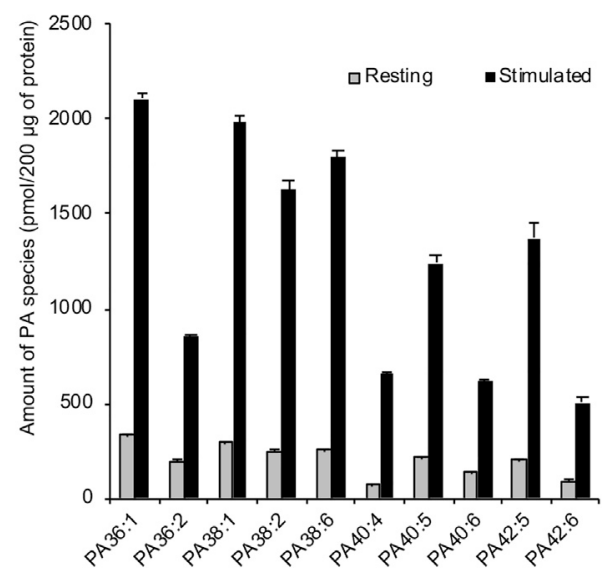

Figure 3. Different PA Species Are Produced at the Plasma Membrane in PC12 Cells Stimulated for Exocytosis

(A) Effect of high $\mathrm{K}^{+}$stimulation on the total amount of PA present in plasma and secretory granule membranes. Crude membranes obtained from $400 \times 10^{6} \mathrm{PC} 12$ cells (maintained in resting condition or stimulated for $10 \mathrm{~min}$ with $59 \mathrm{mM} \mathrm{K}^{+}$) were subjected to ultracentrifugation on the sucrose gradient to separate plasma and secretory granule membranes. Total PA quantified by mass spectrometry is expressed in nanomoles of PA per milligram of membrane protein. Data are expressed as means \pm SD $\left(n=4\right.$ independent cell cultures; ${ }^{* \star *} p<0.001$ compared with resting condition). The inset illustrates a western blot control of plasma membrane (PM) and secretory granule (Gr) fractions (20 $\mu \mathrm{g}$ of protein) performed with anti-CgA and anti-SNAP25 antibodies.

(B) Mass spectrometry identification and quantification of the 10 most abundant PA species present in the plasma membrane of $\mathrm{PC} 12$ cells maintained in resting condition (resting) or stimulated for $10 \mathrm{~min}$ with $59 \mathrm{mM} \mathrm{K}^{+}$ (stimulated). Data are means $\pm \operatorname{SD}(n=4)$. last third was more distantly distributed (Figure 4B). Most gold particles found near the granules appeared to be closely associated to structures previously identified as possible actin cables anchoring secretory granules to the plasma membrane (Gabel et al., 2015) (Figure 4B). Thus, in good correlation with the data obtained by amperometry, functionally linking PA to late stages of exocytosis, these observations reveal that secretagogue-evoked stimulation triggers the production of various PA species at the plasma membrane, preferentially located near the sites of active exocytosis close to docked granules.

\section{Distinct PA Species Rescue Different Steps of Regulated Exocytosis}

Based on pioneering studies from Amatore et al. (2006), we decided to undertake rescue experiments in PLD1-inhibited chromaffin cells to investigate whether the different PA species produced at the plasma membrane might exert distinct functions in the exocytotic pathway. Using bovine chromaffin cells expressing the PA probe Spo20p-GFP, we first performed a series of experiments to assess whether the addition of exogenous PA (an eggPA mixture or various forms of a specific $P A$ ) could reach the inner leaflet of the plasma membrane and increase the amounts of plasma membrane PA to levels similar to those reached in stimulated cells, as measured by quantifying the recruitment of Spo20p-GFP to the cell periphery (Figure S6A). Provision of different types of extracellular $P A$ recapitulated the recruitment of Spo20p-GFP to the plasma membrane observed in stimulated cells, indicating that under those conditions, PA levels in the inner leaflet of the plasma membrane were increased (Figure S6B). We then examined the effect of external PA provision on bovine chromaffin cell secretory activity quantified by fluorescence spectroscopy (Gabel et al., 2019). Incubation of cultured chromaffin cells with increasing amounts of the egg-PA mixture did not significantly affect catecholamine secretion per se, but it rescued secretion from cells treated with the PLD1 inhibitors CAY93 (Figure 5A) and FIPI (Figure 5B). Moreover, the mono-unsaturated (PA 36:1) and di-unsaturated (PA 36:2) forms of PA were able to rescue secretion in FIPI-treated cells, whereas the poly-unsaturated PA 40:6 had no effect (Figure 5B). PA 44:12, a form containing two DHA fatty acid chains that was not found in our lipidomic analyses, had also no rescue effect on secretion (Figure 5B).

At the single-cell level, the effects of exogenous PA on individual granule exocytosis were analyzed by amperometry (Figure 5 C). Provision of an egg-PA mixture in the cell incubation medium rescued the number of exocytotic events (spikes) in bovine chromaffin cells incubated with FIPI (Figure 5C). Mono-unsaturated (PA 36:1) and di-unsaturated (PA 36:2) forms of PA rescued the number of exocytotic events, whereas saturated (not shown) or poly-unsaturated forms of PA (PA 40:6 and PA 44:12) were ineffective (Figure $5 \mathrm{C}$ ). However, despite restoring the number of amperometric spikes in FIPI-treated cells, mono-unsaturated (PA 36:1) and di-unsaturated (PA 36:2) PA were unable to restore the shape of the spikes, which remained broader with a longer foot, whereas the PA mixture and specifically the omega-3 form of PA (PA 40:6) rescued these spike-kinetic parameters (Figure $5 \mathrm{C}$ ). In other words, mono-unsaturated and di-unsaturated forms of PA(PA 36:1 and PA 36:2) seemed to be specifically implicated in the number of exocytotic events, perhaps by favoring granule recruitment and/or docking, whereas poly-unsaturated omega-3 PA (PA 40:6) promoted fusion pore dilation.

We also examined the effect of PA provision on the number of docked granules observed on plasma membrane sheets prepared from resting or high $\mathrm{K}^{+}$-stimulated chromaffin cells (Figure 6A). PLD1 inhibition by FIPI treatment significantly reduced the number of secretory granules found attached to the inner face of the plasma membrane in high $\mathrm{K}^{+}$-stimulated cells (Figures $6 \mathrm{~A}$ and $6 \mathrm{~B}$ ). Incubation of cells with the egg-PA mixture almost prevented this inhibitory effect of FIPI on granule docking (Figure 6B). Most interestingly, the mono-unsaturated PA 36:1 also significantly restored the number of docked granules in PLD1depleted chromaffin cells stimulated with high $\mathrm{K}^{+}$, whereas the omega-3 form PA 40:6 had no effect (Figure 6B), in good agreement with the observation that PA 36:1, but not PA 40:6, rescued the number of amperometric exocytotic events. 

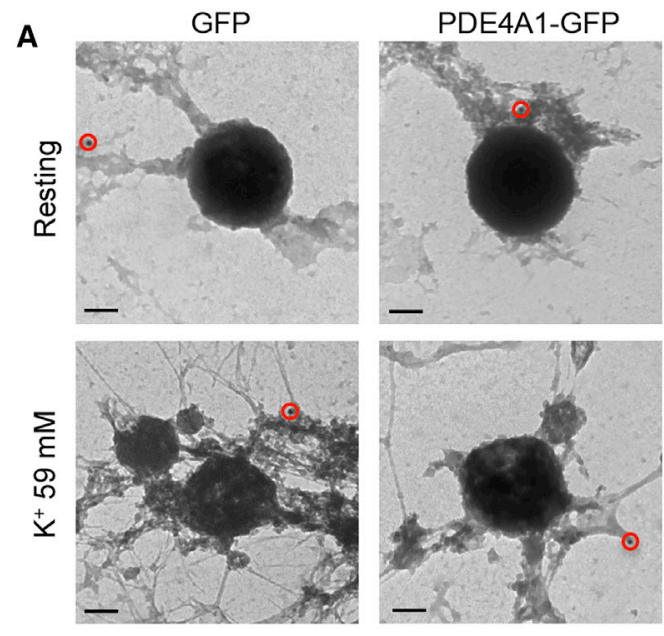

B
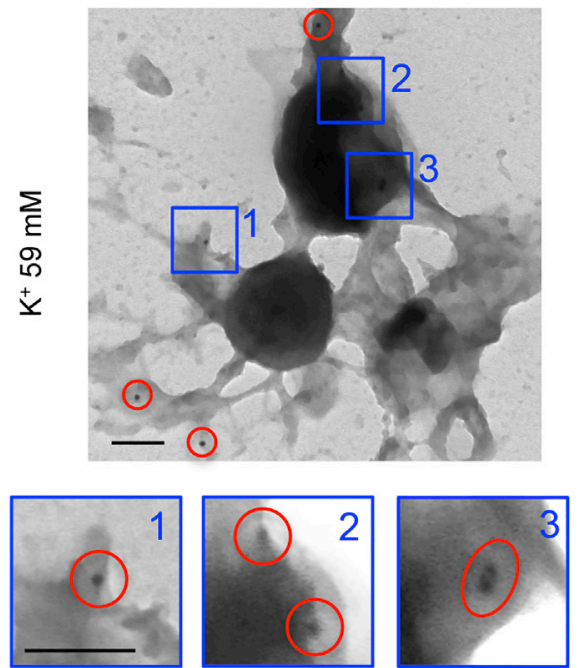
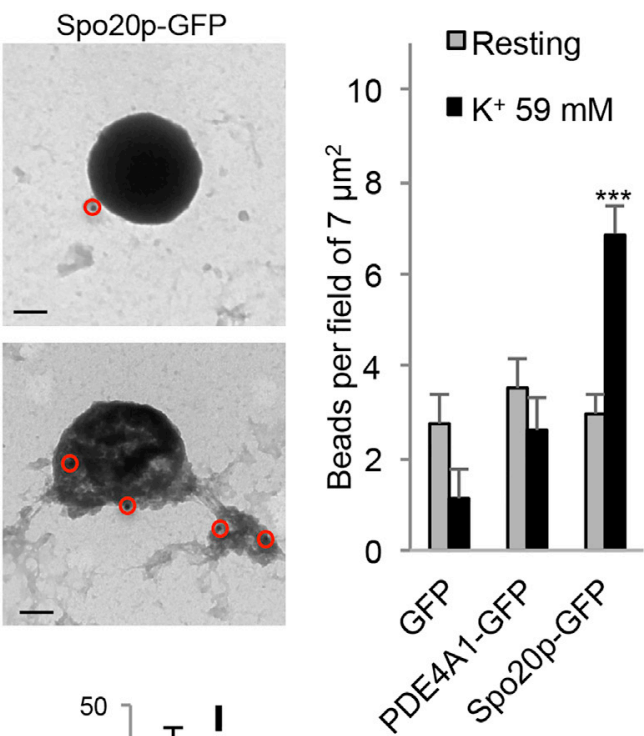

\author{
4 口Resting \\ - $\mathrm{K}^{+} 59 \mathrm{mM}$
}

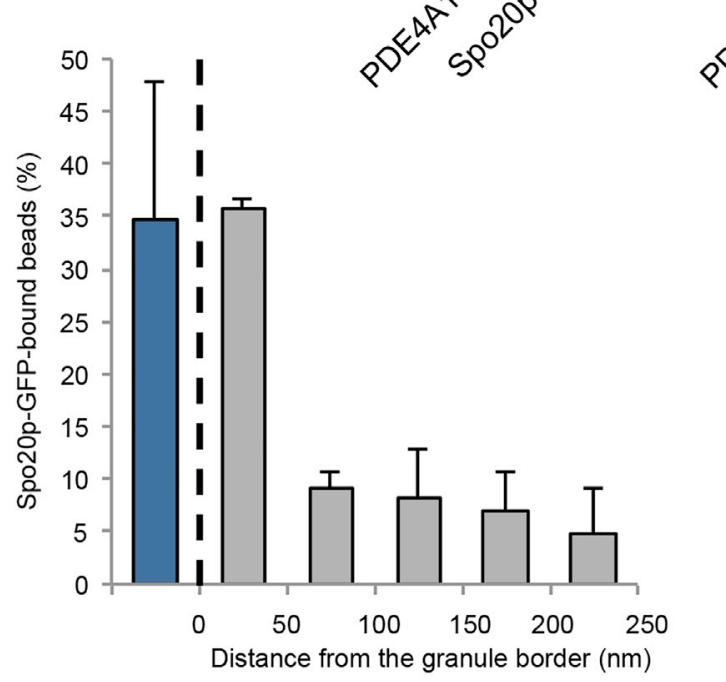

Figure 4. Secretagogue-Evoked Stimulation Triggers the Production of PA at the Plasma Membrane Close to Docked Granules in Chromaffin Cells

(A) Electron micrograph of plasma membrane sheets prepared from bovine chromaffin cells expressing the PA sensors Spo20p-GFP, PDE4A1-GFP, or GFP as control. Cells were stimulated for 10 min with $59 \mathrm{mM} \mathrm{K}^{+}$or maintained under resting conditions. Immunolabeling of GFP was revealed with $15 \mathrm{~nm}$ gold-particleconjugated secondary antibodies. Red circles highlight gold particles. Scale bar, $100 \mathrm{~nm}$. The histograms show the mean number of gold beads per $7 \mu \mathrm{m}^{2}$ field and the mean number of gold beads associated with secretory granules when present within $250 \mathrm{~nm}$ of a granule border. The background signal in nontransfected cells was subtracted. Error bars indicate \pm SEM ( $n>65$ images from two independent experiments; ${ }^{* * *} p<0.001$ compared with resting condition). (B) Illustration of anti-GFP labeling in plasma membrane sheets prepared from high $\mathrm{K}^{+}$-stimulated chromaffin cells expressing Spo20p-GFP; scale bar, 100 nm. Zooms illustrate the presence of gold particles close to secretory granules and actin structures; scale bar, $100 \mathrm{~nm}$. The mean number of gold particles found in the area corresponding to the secretory granule (blue column) and up to $250 \mathrm{~nm}$ from the granule border was quantified. Error bars indicate $\pm S D(n>65 \mathrm{images}$ from two independent experiments).

To conclude, based on the present findings, we propose that the various stages underlying dense-core granule exocytosis require distinct PA species. Mono-unsaturated and possibly diunsaturated forms of PA are preferentially implicated in granule docking, whereas poly-unsaturated omega-3 PA favors subsequent fusion pore dilation.

\section{DISCUSSION}

Over the past decade, lipids have emerged as essential partners for proteins in membrane trafficking, and among them, the nega- tively charged, cone-shaped PA is now recognized as a key mediator in membrane fusion and vesicle exocytosis events. PA lies in the middle of three enzymatic biosynthetic routes (Pokotylo et al., 2018; Tanguy et al., 2019a; Zegarlińska et al., 2018). In neurons and neuroendocrine cells, the development of molecular tools let us to identify PLD1 as the key enzyme responsible for PA synthesis during exocytosis (Humeau et al., 2001; Vitale et al., 2001). Investigation of the upstream signaling pathways indicated that full activation of PLD1 required interactions with several members of the small guanosine triphosphatase (GTPase) family, including ARF, Ral, and Rac (Béglé et al., 2009; Momboisse et al., 2009; 
A

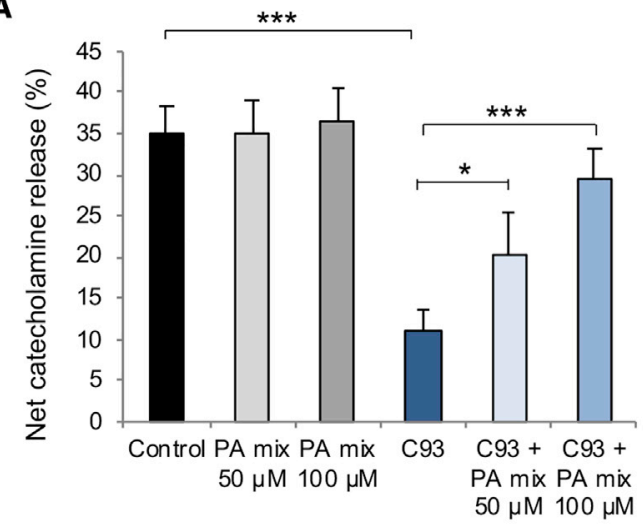

B

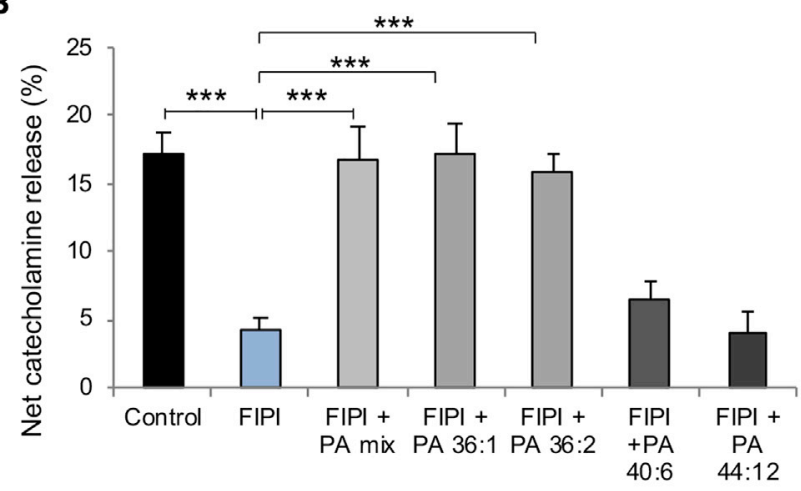

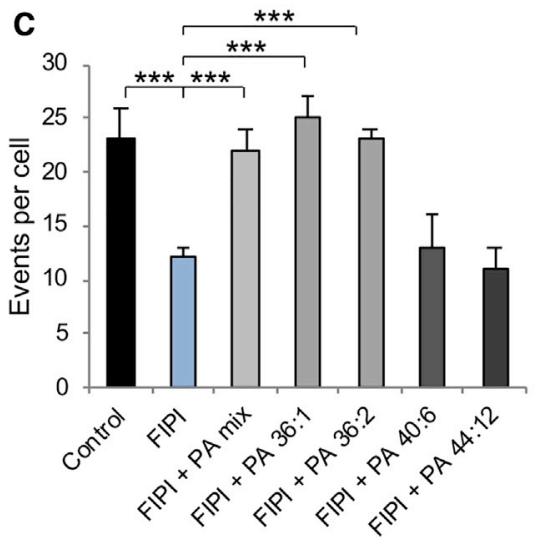
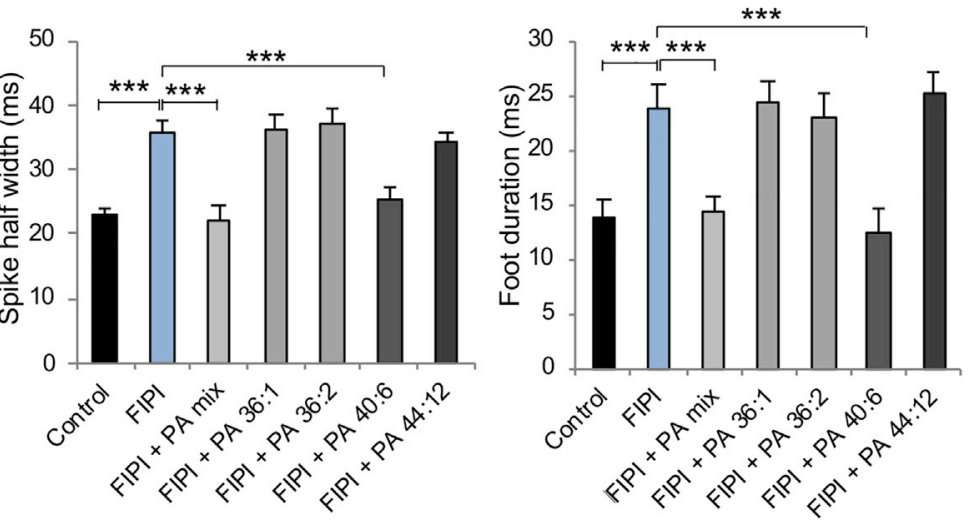

Figure 5. Different PA Species Rescue Distinct Stages of Exocytosis

(A) Bovine chromaffin cells were treated with $50 \mathrm{nM} \mathrm{C93}$ or vehicle (control) for $1 \mathrm{~h}$ and incubated with the indicated concentration of a PA mixture for 15 min before stimulation with $10 \mu \mathrm{M}$ nicotine. Catecholamine release of the cell population was estimated using the adrenolutine assay, and basal release was subtracted to obtain the net catecholamine secretion. Data are given as the mean values $\pm \mathrm{SD}$ obtained in three experiments performed on different cell cultures ( $\mathrm{n}=$ $3 ;{ }^{*} \mathrm{p}<0.05,{ }^{\star \star *} \mathrm{p}<0.001$ compared with control).

(B) Bovine chromaffin cells were treated with $750 \mathrm{nM} \mathrm{FIPI}$ or vehicle (control) for $1 \mathrm{~h}$ and incubated with $100 \mu \mathrm{M}$ of the PA mix or $10 \mu \mathrm{M}$ of the indicated PA species for 15 min before stimulation with $10 \mu \mathrm{M}$ nicotine. Net catecholamine release was obtained as in (A). Data are given as the mean values \pm SD obtained from three independent experiments performed on cell cultures $\left(n=3 ;{ }^{\star * *} p<0.001\right.$ compared with control).

(C) Chromaffin cells were treated with $750 \mathrm{nM}$ FIPI or vehicle (control) for $1 \mathrm{~h}$ and incubated with $100 \mu \mathrm{M}$ of the indicated PA for 15 min before stimulation with a local application of Locke's solution containing $100 \mathrm{mM} \mathrm{K}^{+}$for $10 \mathrm{~s}$. Single-cell secretion was monitored by carbon fiber amperometry. Data are expressed as means $\pm S D$ ( $n>75$ cells for each condition from three independent cell cultures). Mono-unsaturated PA rescues the number of amperometric events, whereas poly-unsaturated PA restores spike parameters $\left({ }^{\star \star \star} \mathrm{p}<0.001\right.$ compared with control).

Vitale et al., 2005), and phosphorylation by a ribosomal S6 serine/ threonine kinase (Zeniou-Meyer et al., 2008), revealing sophisticated regulation of PA production in cells undergoing exocytosis. Yet like all phospholipids, PA comes in different flavors based on its fatty acyl chain composition, with up to 40 PA species found in mammals. We show here that PLD1 promotes the synthesis of distinct PA species at the plasma membrane granule docking sites dedicated to specific steps of exocytosis. It is tempting to propose that the multimodal activation of PLD1 might to some extent be linked to a spatial and temporal production of these different PA species at the sites of exocytosis, making PA an ideal signaling integrator for regulated secretion.

We observed that mono-unsaturated and di-unsaturated PA are able to regulate the docking of secretory granules and thereby the number of secretory events, although the omega-3 poly-unsaturated PA regulates fusion pore dynamics and thereby potentially modulates the type and/or the amount of molecules released per vesicle. These PA species are among the few PA recently shown to be synthesized by PLD1 in the mouse dorsal hippocampus, implicated in pyramidal neuron dendritic branching, and linked to hippocampus-specific tasks like novel object recognition and social interaction (Santa-Marinha et al., 2020). Previous capacitance recordings from chromaffin cells silenced for PLD1 using a small interfering RNA (siRNA) strategy suggested that PLD1 controls the number of fusion-competent secretory granules at the plasma membrane without affecting earlier recruitment or docking steps (Zeniou-Meyer et al., 2007). Here, using chromaffin cells from PLD1 knockout mice and amperometric recordings, we observed that PLD1-mediated PA plays a role that seems more complex than previously anticipated, because it is implicated in the late fusion step and in earlier events such as granule recruitment or docking steps. This apparent discrepancy with our previous results might be linked to the presence of residual PLD1 in siRNAtreated cells compared with genetically modified $\mathrm{Pld} 1^{-1-}$ cells 


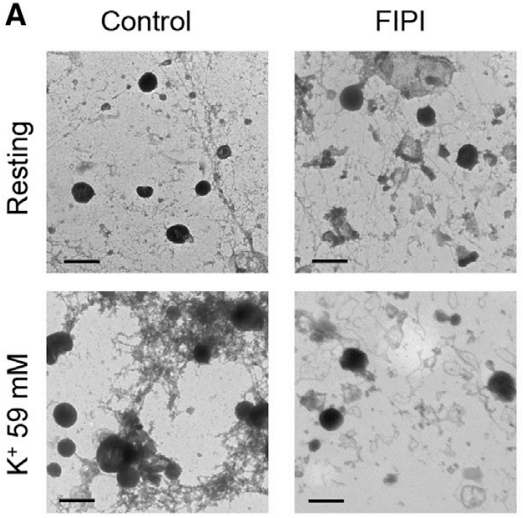

B Control $\square$ FIPI + PA mix

口FIPI $\quad$ FFIPI + PA 36:1

$\square F I P I+P A 40: 6$

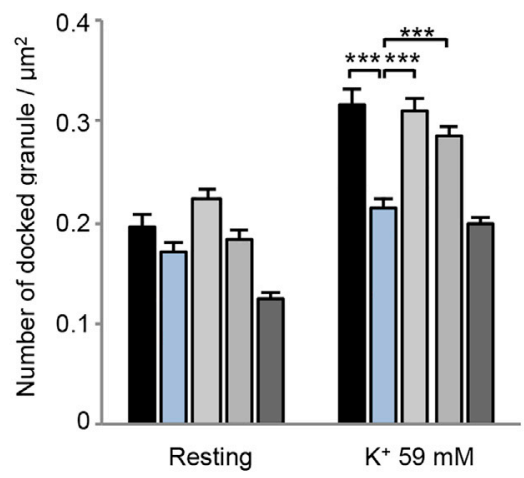

Figure 6. Mono-unsaturated PA Rescues the Number of Docked Granules in PLD1-Inhibited Chromaffin Cells

(A) Bovine chromaffin cells were incubated with $750 \mathrm{nM}$ FIPI or vehicle (control) for $1 \mathrm{~h}$ to inhibit PLD1. Cells were then stimulated for $5 \mathrm{~min}$ with $59 \mathrm{mM} \mathrm{K}^{+}$or maintained under resting conditions. Electron micrographs of plasma membrane sheets from resting or stimulated chromaffin cells treated or not with FIPI are shown. Scale bar, $500 \mathrm{~nm}$.

(B) Bovine chromaffin cells were incubated for $15 \mathrm{~min}$ with $100 \mu \mathrm{M}$ of the indicated PA in the presence or absence of $750 \mathrm{nM} \mathrm{FIPI}$, before being stimulated for 5 min with $59 \mathrm{mM} \mathrm{K}^{+}$or maintained under resting conditions. The number of granules morphologically docked on plasma membrane sheets was quantified manually on random fields of $45 \mu \mathrm{m}^{2}$. Data are presented as means \pm SEM $(n>60$ images from three cell cultures for each condition; ${ }^{\star \star \star} p<0.001$ compared with control, Mann-Whitney test).

(Zeniou-Meyer et al., 2007). Hence, local and timely accumulation of PA produces distinct membrane trafficking and signaling effects that might define pleiotropic functions for PA in regulated exocytosis (Tanguy et al., 2019a). These include the recruitment of proteins involved in priming or even fusion events; the stimulation of phosphatidylinositol 4,5-bisphosphate $\left(\mathrm{PI}(4,5) \mathrm{P}_{2}\right)$ production, a lipid well known for its role in the priming steps of exocytosis (Martin, 2012); and as previously proposed, the promotion of negative curvature in lipid bilayers generating physically fusion-competent membranes (Martin, 2012), as well as many steps of vesicular trafficking in neurosecreting cells (Di Paolo and De Camilli, 2006). Altering $\mathrm{PI}(4,5) \mathrm{P}_{2}$ levels in neuroendocrine cells affected both docking and fusion (Tryoen-Tóth et al., 2013; Walter et al., 2017), as revealed here for PA, but whether the action of PA involves directly modulation of $\mathrm{PI}(4,5) \mathrm{P}_{2}$ levels remains to be determined.

Among the nearly 50 proteins that have been shown to date to bind to PA (Pokotylo et al., 2018; Tanguy et al., 2019a; Zegarlińska et al., 2018), several are interesting candidates in regulating exocytosis. For instance, the soluble $N$-ethylmaleimide-sensitive factor attachment protein receptor (SNARE) protein syntaxin-1 has been shown to bind to several anionic lipids, including phosphoinositides and PA (Lam et al., 2008). In vitro experiments support the idea that PA directly affects SNARE complex assembly and/or zippering (Mima and Wickner, 2009), although the functions of the different PA forms have not been yet tested. Mutations in the polybasic site abolishing the ability of syntaxin 1 to bind PA resulted in a reduction in the number of amperometric spikes and an increase in the pre-spike foot duration (Lam et al., 2008), similar to the amperometric traces obtained in $P l d 1^{-1-}$ mouse chromaffin cells or in bovine chromaffin cells with PLD1 activity pharmacologically inhibited. A similar domain enriched in positive charges that could potentially bind to anionic PA has been described in vesicular SNAREs and reported to be required for membrane destabilization and fusion (Rathore et al., 2019). The actin cytoskeleton, well known to influence several steps leading to exocytosis in neuroendocrine cells (Gutiérrez, 2012; Li et al., 2018; Malacombe et al., 2006), is also a major potential target of PA. First viewed as a physical barrier preventing granule recruitment, cortical actin also acts as an active network that has been proposed to stabilize granule docking sites, control fusion pore lifetime, and/or directly expel granule secretory content. Several actin binding proteins have been shown to bind PA, including regulators of the Rho family of small GTPases, which play a key role in providing the actin structures required for the late stages of exocytosis (Gasman et al., 2004; Houy et al., 2015; Malacombe et al., 2006). Annexin A2, shown to promote actin bundling required for the structural and spatial organization of the exocytotic sites at the plasma membrane (Gabel et al., 2015), also binds to anionic lipids, including PA (Gabel et al., 2019). Indeed, in stimulated chromaffin cells, PA is found in membrane micro-domains closely associated to the large annexin A2-mediated actin bundles anchoring secretory granules to the plasma membrane (Gabel et al., 2015).

The observation that the omega- 3 form of PA specifically regulates the late stages of exocytosis, most likely fusion pore enlargement, expands our knowledge on the key cellular function of polyunsaturated fatty acids (PUFAs) in neurons and neuroendocrine cells. It is known that a high-PUFA diet has cognitive beneficial effects, but the underlying cellular mechanisms remain elusive (Thomas et al., 2016). A first hint came from the observation that secretory and synaptic vesicles are particularly enriched in PUFAs (Takamori et al., 2006). More recently, it was shown by various biophysical and cellular assays that PUFAs increase the ability of dynamin and endophilin to deform membranes and support endocytosis compared with mono-unsaturated fatty acids (MUFAs) (Pinot et al., 2014). Because of the higher flexibility of their acyl chain, PUFAs adapt their conformation to membrane curvature, thereby reducing the energetic cost of various membrane deformations and facilitating fission or fusion events (Manni et al., 2018). Furthermore the effect of PUFAs on membrane packing is less disturbing than that of MUFAs, and phospholipids containing PUFAs might soften various molecular stresses in the hydrophobic core of the membrane (Barelli and Antonny, 2016). PA is a coneshaped lipid that is likely to modulate membrane topology by accumulating at curved membrane areas, resulting in the merging of the inner leaflet of the plasma membrane and the outer leaflet of the vesicular membrane, particularly in the presence of calcium (Jouhet, 2013). Thus, in the course of exocytosis, synthesis of PA containing a PUFA side chain might well facilitate the dilation of the fusion pore but also the formation of compensatory endocytic vesicles. Interestingly, using super-resolution microscopy 
to visualize dense-core granule fusion in chromaffin cells, two distinct modes of fusion associated with either a large or a narrow fusion pore have recently been described (Shin et al., 2018, 2020). It is tempting to propose that the pool of omega-3 PA present at the granule docking site might influence the choice between these two fusion modes. Alternatively, based on amperometric measurements, there is evidence that during exocytosis, the fusion pore dilates but is able to close again, leading to only partial release of the granule load (Ren et al., 2016). Gu et al. (2019) described that repetitive stimuli, while depleting catecholamine storage inside individual granules, induced an increase of the fraction of catecholamine released per granule, suggesting that at the single-granule level, repetitive stimuli favor the formation of a longer-duration fusion pore. The authors suggested that upon repetitive stimuli, the composition of membrane phospholipids in the exocytotic active zones is altered, with perhaps a higher ratio of high-curvature lipid species over low-curvature ones. At the electron-microscopy level using the Spo20p PA sensor, we observed in stimulated chromaffin cells that PA is found not only on the cytosolic leaflet of the plasma membrane but also on the outer leaflet of docked secretory granules. Because PLD1 is not associated with secretory granules, this intriguing observation suggested either that PA can be formed at the Golgi level during secretory granule biogenesis (Carmon et al., 2020) or that PA formed in the plasma membrane might to some extent diffuse via lipid mixing to the granule membrane at the docking site. The later possibility fits well with the idea that partial release might be the dominant mode of exocytosis with fusion pore opening and closing, leading to some extent to lipid mixing between plasma and granule membranes. Consequently, elevation of PA levels in the granule membrane upon repetitive stimuli might well increase the duration of the fusion pore. Being under the control of several upstream signaling pathways, PLD1 is particularly suited to provide the link between activity-induced plasticity and fraction of release at the single-granule level.

One of the most exciting developments in understanding neuronal synaptic function has been the increasing interest in the role of lipids, and among them, PA appears to play a prominent role (Raben and Barber, 2017). We are only on the verge of fully appreciating the interconnections in neuronal function among $\mathrm{PA}, \mathrm{PI}(4,5) \mathrm{P}_{2}$, and diacylglycerol (DAG), which are all tightly intertwined in their multiple metabolic pathways (Di Paolo and De Camilli, 2006). For instance, alteration of the tight PA/DAG equilibrium in neurons might be one of the main sources for neuronal dysfunction in fragile $X$ mental retardation (Tabet et al., 2016), whereas PA synthesis appears altered in Coffin-Lowry syndrome, an intellectual disability disease (Zeniou-Meyer et al., 2008), as well as in Alzheimer disease (Oliveira et al., 2010). Although the functions of individual PA species in these pathologies remain to be precisely established, the possibility described here to restore neuroendocrine exocytosis by provision of adequate PA opens a route toward a better understanding of the importance of specific fatty acids in diet to improve human health.

\section{STAR $\star$ METHODS}

Detailed methods are provided in the online version of this paper and include the following:
- KEY RESOURCES TABLE

- RESOURCE AVAILABILITY

O Lead Contact

- Materials Availability

- Data and Code Availability

- EXPERIMENTAL MODEL AND SUBJECT DETAILS

Ethics Statement and Mouse Lines

O Reagents

O Primary Culture of Chromaffin and PC12 Cells

- METHOD DETAILS

Transfection

○ Amperometry

O Secretion and catecholamine ELISA assays

○ Western blotting

O Subcellular fractionation and PA lipidomic analysis

O Transmission electron microscopy of chromaffin cells in situ and secretory granule docking analysis

- Plasma membrane sheet preparation, immunolabeling and transmission electron microscopy

O Confocal microscopy

- QUANTIFICATION AND STATISTICAL ANALYSIS

○ Data selection

O Statistical Analysis

\section{SUPPLEMENTAL INFORMATION}

Supplemental Information can be found online at https://doi.org/10.1016/j. celrep.2020.108026.

\section{ACKNOWLEDGMENTS}

We acknowledge the Plateforme Imagerie In Vitro of Neuropôle at CNRS UPS3256 , the municipal slaughterhouse of Haguenau (France) for providing the bovine adrenal glands, and the animal facility of Institut des Neurosciences Cellulaires et Intégratives (Chronobiotron UMS 3415) for handling mice. We also thank Dr. B. Nieswandt (University of Wurtzburg) and Dr. G. Di Paolo (Denali Therapeutics) for providing PId1 and PId2 mice lines, respectively. This work was supported by grants from the Fondation pour la Recherche Médicale (DEI20151234424) and the Agence Nationale pour la Recherche (ANR-19CE44-0019) to N.V.

\section{AUTHOR CONTRIBUTIONS}

Experiments were performed and analyzed by E.T., P.C.d.B., N.K., M.-R.A., Q.W., A.-M.H., J.R., L.F., and S.C.-G. Image analysis was performed by E.T., P.C.d.B., and Q.W. with the help of S.C.-G. and S.O., whereas L.F. was involved in the lipidomics. P.-Y.R., M.M.-H., S.C.-G., M.-F.B., and N.V. designed experiments and discussed the evolving project. N.V. wrote the manuscript and provided financial grant support. All authors reviewed the manuscript.

\section{DECLARATION OF INTERESTS}

The authors declare no competing interests.

Received: February 28, 2020

Revised: June 16, 2020

Accepted: July 21, 2020

Published: August 18, 2020 


\section{CellPress}

\section{REFERENCES}

Amatore, C., Arbault, S., Bouret, Y., Guille, M., Lemaitre, F., and Verchier, Y. (2006). Regulation of exocytosis in chromaffin cells by trans-insertion of lysophosphatidylcholine and arachidonic acid into the outer leaflet of the cell membrane. ChemBioChem 7, 1998-2003.

Ammar, M.-R., Humeau, Y., Hanauer, A., Nieswandt, B., Bader, M.-F., and Vitale, N. (2013). The Coffin-Lowry syndrome-associated protein RSK2 regulates neurite outgrowth through phosphorylation of phospholipase D1 (PLD1) and synthesis of phosphatidic acid. J. Neurosci. 33, 19470-19479.

Ammar, M.R., Thahouly, T., Hanauer, A., Stegner, D., Nieswandt, B., and Vitale, N. (2015). PLD1 participates in BDNF-induced signalling in cortical neurons. Sci. Rep. 5, 14778.

Bader, M.-F., and Vitale, N. (2009). Phospholipase D in calcium-regulated exocytosis: lessons from chromaffin cells. Biochim. Biophys. Acta 1791, 936-941.

Barelli, H., and Antonny, B. (2016). Lipid unsaturation and organelle dynamics. Curr. Opin. Cell Biol. 41, 25-32.

Béglé, A., Tryoen-Tóth, P., de Barry, J., Bader, M.-F., and Vitale, N. (2009). ARF6 regulates the synthesis of fusogenic lipids for calcium-regulated exocytosis in neuroendocrine cells. J. Biol. Chem. 284, 4836-4845.

Bligh, E.G., and Dyer, W.J. (1959). A rapid method of total lipid extraction and purification. Can. J. Biochem. Physiol. 37, 911-917.

Borges, R., Travis, E.R., Hochstetler, S.E., and Wightman, R.M. (1997). Effects of external osmotic pressure on vesicular secretion from bovine adrenal medullary cells. J. Biol. Chem. 272, 8325-8331.

Carmon, O., Laguerre, F., Riachy, L., Delestre-Delacour, C., Wang, Q., Tanguy, E., Jeandel, L., Cartier, D., Thahouly, T., Haeberlé, A.-M., et al. (2020). Chromogranin A preferential interaction with Golgi phosphatidic acid induces membrane deformation and contributes to secretory granule biogenesis. FASEB J. 34, 6769-6790.

Caumont, A.S., Vitale, N., Gensse, M., Galas, M.C., Casanova, J.E., and Bader, M.F. (2000). Identification of a plasma membrane-associated guanine nucleotide exchange factor for ARF6 in chromaffin cells. Possible role in the regulated exocytotic pathway. J. Biol. Chem. 275, 15637-15644.

Chasserot-Golaz, S., Vitale, N., Sagot, I., Delouche, B., Dirrig, S., Pradel, L.A., Henry, J.P., Aunis, D., and Bader, M.F. (1996). Annexin II in exocytosis: catecholamine secretion requires the translocation of p36 to the subplasmalemmal region in chromaffin cells. J. Cell Biol. 133, 1217-1236.

Choi, W.S., Kim, Y.M., Combs, C., Frohman, M.A., and Beaven, M.A. (2002). Phospholipases D1 and D2 regulate different phases of exocytosis in mast cells. J. Immunol. 168, 5682-5689.

Corrotte, M., Chasserot-Golaz, S., Huang, P., Du, G., Ktistakis, N.T., Frohman, M.A., Vitale, N., Bader, M.-F., and Grant, N.J. (2006). Dynamics and function of phospholipase $\mathrm{D}$ and phosphatidic acid during phagocytosis. Traffic 7 , 365-377.

Di Paolo, G., and De Camilli, P. (2006). Phosphoinositides in cell regulation and membrane dynamics. Nature 443, 651-657.

Di Paolo, G., and Kim, T.-W. (2011). Linking lipids to Alzheimer's disease: cholesterol and beyond. Nat. Rev. Neurosci. 12, 284-296.

Disse, J., Vitale, N., Bader, M.-F., and Gerke, V. (2009). Phospholipase D1 is specifically required for regulated secretion of von Willebrand factor from endothelial cells. Blood 113, 973-980.

Elvers, M., Stegner, D., Hagedorn, I., Kleinschnitz, C., Braun, A., Kuijpers, M.E.J., Boesl, M., Chen, Q., Heemskerk, J.W.M., Stoll, G., et al. (2010). Impaired alpha(IIb)beta(3) integrin activation and shear-dependent thrombus formation in mice lacking phospholipase D1. Sci. Signal. 3, ra1.

Estévez-Herrera, J., González-Santana, A., Baz-Dávila, R., Machado, J.D., and Borges, R. (2016). The intravesicular cocktail and its role in the regulation of exocytosis. J. Neurochem. 137, 897-903.

Fathali, H., and Cans, A.-S. (2018). Amperometry methods for monitoring vesicular quantal size and regulation of exocytosis release. Pflugers Arch. 470, 125-134.
Gabel, M., Delavoie, F., Demais, V., Royer, C., Bailly, Y., Vitale, N., Bader, M.-F., and Chasserot-Golaz, S. (2015). Annexin A2-dependent actin bundling promotes secretory granule docking to the plasma membrane and exocytosis. J. Cell Biol. 210, 785-800.

Gabel, M., Delavoie, F., Royer, C., Tahouly, T., Gasman, S., Bader, M.-F., Vitale, N., and Chasserot-Golaz, S. (2019). Phosphorylation cycling of Annexin A2 Tyr23 is critical for calcium-regulated exocytosis in neuroendocrine cells. Biochim. Biophys. Acta Mol. Cell Res. 1866, 1207-1217.

Gasman, S., Chasserot-Golaz, S., Malacombe, M., Way, M., and Bader, M.-F. (2004). Regulated exocytosis in neuroendocrine cells: a role for subplasmalemmal Cdc42/N-WASP-induced actin filaments. Mol. Biol. Cell 15, 520-531. Gu, C., Larsson, A., and Ewing, A.G. (2019). Plasticity in exocytosis revealed through the effects of repetitive stimuli affect the content of nanometer vesicles and the fraction of transmitter released. Proc. Natl. Acad. Sci. USA 116, 21409-21415.

Gutiérrez, L.M. (2012). New insights into the role of the cortical cytoskeleton in exocytosis from neuroendocrine cells. Int. Rev. Cell Mol. Biol. 295, 109-137.

Holland, P., Knævelsrud, H., Søreng, K., Mathai, B.J., Lystad, A.H., Pankiv, S., Bjørndal, G.T., Schultz, S.W., Lobert, V.H., Chan, R.B., et al. (2016). HS1BP3 negatively regulates autophagy by modulation of phosphatidic acid levels. Nat. Commun. 7, 13889.

Houy, S., Estay-Ahumada, C., Croisé, P., Calco, V., Haeberlé, A.-M., Bailly, Y., Billuart, P., Vitale, N., Bader, M.-F., Ory, S., and Gasman, S. (2015). Oligophrenin-1 Connects Exocytotic Fusion to Compensatory Endocytosis in Neuroendocrine Cells. J. Neurosci. 35, 11045-11055.

Humeau, Y., Vitale, N., Chasserot-Golaz, S., Dupont, J.L., Du, G., Frohman, M.A., Bader, M.F., and Poulain, B. (2001). A role for phospholipase D1 in neurotransmitter release. Proc. Natl. Acad. Sci. USA 98, 15300-15305.

Jouhet, J. (2013). Importance of the hexagonal lipid phase in biological membrane organization. Front. Plant Sci. 4, 494.

Kassas, N., Tryoen-Tóth, P., Corrotte, M., Thahouly, T., Bader, M.-F., Grant, N.J., and Vitale, N. (2012). Genetically encoded probes for phosphatidic acid. Methods Cell Biol. 108, 445-459.

Kassas, N., Tanguy, E., Thahouly, T., Fouillen, L., Heintz, D., Chasserot-Golaz, S., Bader, M.-F., Grant, N.J., and Vitale, N. (2017). Comparative Characterization of Phosphatidic Acid Sensors and Their Localization during Frustrated Phagocytosis. J. Biol. Chem. 292, 4266-4279.

Kim, T., Tao-Cheng, J.H., Eiden, L.E., and Loh, Y.P. (2001). Chromogranin A, an "on/off" switch controlling dense-core secretory granule biogenesis. Cell 106, 499-509.

Lam, A.D., Tryoen-Toth, P., Tsai, B., Vitale, N., and Stuenkel, E.L. (2008). SNARE-catalyzed fusion events are regulated by Syntaxin1A-lipid interactions. Mol. Biol. Cell 19, 485-497.

Li, P., Bademosi, A.T., Luo, J., and Meunier, F.A. (2018). Actin Remodeling in Regulated Exocytosis: Toward a Mesoscopic View. Trends Cell Biol. 28, 685-697.

Machado, D.J., Montesinos, M.S., and Borges, R. (2008). Good practices in single-cell amperometry. Methods Mol. Biol. 440, 297-313.

Malacombe, M., Ceridono, M., Calco, V., Chasserot-Golaz, S., McPherson, P.S., Bader, M.-F., and Gasman, S. (2006). Intersectin-1L nucleotide exchange factor regulates secretory granule exocytosis by activating Cdc42. EMBO J. 25, 3494-3503.

Manni, M.M., Tiberti, M.L., Pagnotta, S., Barelli, H., Gautier, R., and Antonny, B. (2018). Acyl chain asymmetry and polyunsaturation of brain phospholipids facilitate membrane vesiculation without leakage. eLife 7, e34394.

Martin, T.F.J. (2012). Role of $\mathrm{PI}(4,5) \mathrm{P}(2)$ in vesicle exocytosis and membrane fusion. Subcell. Biochem. 59, 111-130.

Mima, J., and Wickner, W. (2009). Complex lipid requirements for SNARE- and SNARE chaperone-dependent membrane fusion. J. Biol. Chem. 284, 2711427122.

Momboisse, F., Lonchamp, E., Calco, V., Ceridono, M., Vitale, N., Bader, M.F., and Gasman, S. (2009). betaPIX-activated Rac1 stimulates the activation of 
phospholipase D, which is associated with exocytosis in neuroendocrine cells. J. Cell Sci. 122, 798-806.

Mosharov, E.V., and Sulzer, D. (2005). Analysis of exocytotic events recorded by amperometry. Nat. Methods 2, 651-658.

Nelson, R.K., and Frohman, M.A. (2015). Physiological and pathophysiological roles for phospholipase D. J. Lipid Res. 56, 2229-2237.

Oliveira, T.G., Chan, R.B., Tian, H., Laredo, M., Shui, G., Staniszewski, A., Zhang, H., Wang, L., Kim, T.-W., Duff, K.E., et al. (2010). Phospholipase d2 ablation ameliorates Alzheimer's disease-linked synaptic dysfunction and cognitive deficits. J. Neurosci. 30, 16419-16428.

Pinot, M., Vanni, S., Pagnotta, S., Lacas-Gervais, S., Payet, L.-A., Ferreira, T., Gautier, R., Goud, B., Antonny, B., and Barelli, H. (2014). Lipid cell biology. Polyunsaturated phospholipids facilitate membrane deformation and fission by endocytic proteins. Science 345, 693-697.

Poëa-Guyon, S., Ammar, M.R., Erard, M., Amar, M., Moreau, A.W., Fossier, P., Gleize, V., Vitale, N., and Morel, N. (2013). The V-ATPase membrane domain is a sensor of granular $\mathrm{pH}$ that controls the exocytotic machinery. J. Cell Biol. 203, 283-298.

Pokotylo, I., Kravets, V., Martinec, J., and Ruelland, E. (2018). The phosphatidic acid paradox: Too many actions for one molecule class? Lessons from plants. Prog. Lipid Res. 71, 43-53.

Raben, D.M., and Barber, C.N. (2017). Phosphatidic acid and neurotransmission. Adv. Biol. Regul. 63, 15-21.

Rathore, S.S., Liu, Y., Yu, H., Wan, C., Lee, M., Yin, Q., Stowell, M.H.B., and Shen, J. (2019). Intracellular Vesicle Fusion Requires a Membrane-Destabilizing Peptide Located at the Juxtamembrane Region of the v-SNARE. Cell Rep. 29, 4583-4592.e3.

Ren, L., Mellander, L.J., Keighron, J., Cans, A.-S., Kurczy, M.E., Svir, I., Oleinick, A., Amatore, C., and Ewing, A.G. (2016). The evidence for open and closed exocytosis as the primary release mechanism. Q. Rev. Biophys. 49, e12.

Santa-Marinha, L., Castanho, I., Silva, R.R., Bravo, F.V., Miranda, A.M., Meira, T., Morais-Ribeiro, R., Marques, F., Xu, Y., Point du Jour, K., et al. (2020). Phospholipase D1 Ablation Disrupts Mouse Longitudinal Hippocampal Axis Organization and Functioning. Cell Rep. 30, 4197-4208.e6.

Scott, S.A., Selvy, P.E., Buck, J.R., Cho, H.P., Criswell, T.L., Thomas, A.L., Armstrong, M.D., Arteaga, C.L., Lindsley, C.W., and Brown, H.A. (2009). Design of isoform-selective phospholipase $D$ inhibitors that modulate cancer cell invasiveness. Nat. Chem. Biol. 5, 108-117.

Shin, W., Ge, L., Arpino, G., Villarreal, S.A., Hamid, E., Liu, H., Zhao, W.-D., Wen, P.J., Chiang, H.-C., and Wu, L.-G. (2018). Visualization of Membrane Pore in Live Cells Reveals a Dynamic-Pore Theory Governing Fusion and Endocytosis. Cell 173, 934-945.e12.

Shin, W., Arpino, G., Thiyagarajan, S., Su, R., Ge, L., McDargh, Z., Guo, X., Wei, L., Shupliakov, O., Jin, A., et al. (2020). Vesicle Shrinking and Enlargement Play Opposing Roles in the Release of Exocytotic Contents. Cell Rep. 30, 421431.e7.

Slotkin, T.A., and Seidler, F.J. (1988). Adrenomedullary catecholamine release in the fetus and newborn: secretory mechanisms and their role in stress and survival. J. Dev. Physiol. 10, 1-16.

Su, W., Yeku, O., Olepu, S., Genna, A., Park, J.-S., Ren, H., Du, G., Gelb, M.H., Morris, A.J., and Frohman, M.A. (2009). 5-Fluoro-2-indolyl des-chlorohalopemide (FIPI), a phospholipase D pharmacological inhibitor that alters cell spreading and inhibits chemotaxis. Mol. Pharmacol. 75, 437-446.

Tabet, R., Moutin, E., Becker, J.A.J., Heintz, D., Fouillen, L., Flatter, E., Krężel, W., Alunni, V., Koebel, P., Dembélé, D., et al. (2016). Fragile X Mental Retardation Protein (FMRP) controls diacylglycerol kinase activity in neurons. Proc. Natl. Acad. Sci. USA 113, E3619-E3628.
Takamori, S., Holt, M., Stenius, K., Lemke, E.A., Grønborg, M., Riedel, D., Urlaub, H., Schenck, S., Brügger, B., Ringler, P., et al. (2006). Molecular anatomy of a trafficking organelle. Cell 127, 831-846.

Tanguy, E., Wang, Q., Moine, H., and Vitale, N. (2019a). Phosphatidic Acid: From Pleiotropic Functions to Neuronal Pathology. Front. Cell. Neurosci. 13, 2.

Tanguy, E., Tran Nguyen, A.P., Kassas, N., Bader, M.-F., Grant, N.J., and Vitale, N. (2019b). Regulation of Phospholipase D by Arf6 during Fc $\gamma$ R-Mediated Phagocytosis. J. Immunol. 202, 2971-2981.

Taupenot, L., Mahata, S.K., Wu, H., and O'Connor, D.T. (1998). Peptidergic activation of transcription and secretion in chromaffin cells. Cis and trans signaling determinants of pituitary adenylyl cyclase-activating polypeptide (PACAP). J. Clin. Invest. 101, 863-876.

Thomas, M.H., Pelleieux, S., Vitale, N., and Olivier, J.L. (2016). Dietary arachidonic acid as a risk factor for age-associated neurodegenerative diseases: Potential mechanisms. Biochimie 130, 168-177.

Tryoen-Tóth, P., Chasserot-Golaz, S., Tu, A., Gherib, P., Bader, M.F., Beaumelle, B., and Vitale, N. (2013). HIV-1 Tat protein inhibits neurosecretion by binding to phosphatidylinositol 4,5-bisphosphate. J. Cell Sci. 126, 454-463.

Vitale, N., Mukai, H., Rouot, B., Thiersé, D., Aunis, D., and Bader, M.F. (1993). Exocytosis in chromaffin cells. Possible involvement of the heterotrimeric GTP-binding protein G(o). J. Biol. Chem. 268, 14715-14723.

Vitale, N., Caumont, A.S., Chasserot-Golaz, S., Du, G., Wu, S., Sciorra, V.A., Morris, A.J., Frohman, M.A., and Bader, M.F. (2001). Phospholipase D1: a key factor for the exocytotic machinery in neuroendocrine cells. EMBO J. 20, 2424-2434.

Vitale, N., Chasserot-Golaz, S., Bailly, Y., Morinaga, N., Frohman, M.A., and Bader, M.-F. (2002). Calcium-regulated exocytosis of dense-core vesicles requires the activation of ADP-ribosylation factor (ARF) 6 by ARF nucleotide binding site opener at the plasma membrane. J. Cell Biol. 159, 79-89.

Vitale, N., Mawet, J., Camonis, J., Regazzi, R., Bader, M.-F., and ChasserotGolaz, S. (2005). The Small GTPase RalA controls exocytosis of large dense core secretory granules by interacting with ARF6-dependent phospholipase D1. J. Biol. Chem. 280, 29921-29928.

Walter, A.M., Müller, R., Tawfik, B., Wierda, K.D., Pinheiro, P.S., Nadler, A., McCarthy, A.W., Ziomkiewicz, I., Kruse, M., Reither, G., et al. (2017). Phosphatidylinositol 4,5-bisphosphate optical uncaging potentiates exocytosis. eLife 6, e30203.

Waselle, L., Gerona, R.R.L., Vitale, N., Martin, T.F.J., Bader, M.-F., and Regazzi, R. (2005). Role of phosphoinositide signaling in the control of insulin exocytosis. Mol. Endocrinol. 19, 3097-3106.

Wightman, R.M., Jankowski, J.A., Kennedy, R.T., Kawagoe, K.T., Schroeder, T.J., Leszczyszyn, D.J., Near, J.A., Diliberto, E.J., Jr., and Viveros, O.H. (1991). Temporally resolved catecholamine spikes correspond to single vesicle release from individual chromaffin cells. Proc. Natl. Acad. Sci. USA 88, 10754-10758.

Zegarlińska, J., Piaścik, M., Sikorski, A.F., and Czogalla, A. (2018). Phosphatidic acid-a simple phospholipid with multiple faces. Acta Biochim. Pol. 65, $163-171$.

Zeniou-Meyer, M., Zabari, N., Ashery, U., Chasserot-Golaz, S., Haeberlé, A.M., Demais, V., Bailly, Y., Gottfried, I., Nakanishi, H., Neiman, A.M., et al. (2007). Phospholipase D1 production of phosphatidic acid at the plasma membrane promotes exocytosis of large dense-core granules at a late stage. J. Biol. Chem. 282, 21746-21757.

Zeniou-Meyer, M., Liu, Y., Béglé, A., Olanich, M.E., Hanauer, A., Becherer, U., Rettig, J., Bader, M.F., and Vitale, N. (2008). The Coffin-Lowry syndromeassociated protein RSK2 is implicated in calcium-regulated exocytosis through the regulation of PLD1. Proc. Natl. Acad. Sci. USA 105, 8434-8439. 


\section{STAR $\star M E T H O D S$}

\section{KEY RESOURCES TABLE}

\begin{tabular}{|c|c|c|}
\hline REAGENT or RESOURCE & SOURCE & IDENTIFIER \\
\hline \multicolumn{3}{|l|}{ Antibodies } \\
\hline Anti-CgA & Home made & (Chasserot-Golaz et al., 1996) \\
\hline Anti-PLD1 & Cell Signaling & Cat\# 3832; RRID:AB_2172256 \\
\hline Anti-PLD2 & Cell Signaling & Cat\# 13904; RRID:AB_2798341 \\
\hline HRP-conjugated anti-mouse and anti-rabbit & PerBio & $\begin{array}{l}\text { Cat\# 31430; RRID:AB_228307, 31460; } \\
\text { RRID:AB_228341 }\end{array}$ \\
\hline Anti-SNAP-25 & Covance & Cat\# SMI-81; RRID:AB_2315336 \\
\hline Anti-GFP & Abcam & Cat\# ab290; RRID:AB_303395 \\
\hline Gold particle-conjugated anti-rabbit & Aurion & N/A \\
\hline \multicolumn{3}{|l|}{ Chemicals, Peptides, and Recombinant Proteins } \\
\hline FIPI & Cayman Chemicals & Cat\# 13563 \\
\hline CAY10593 & Cayman Chemicals & Cat\# 13206 \\
\hline CAY10594 & Cayman Chemicals & Cat\# 13207 \\
\hline Lipofectamine 2000 & Thermo Scientific & Cat\# 11668019 \\
\hline 1-stearoyl-2-oleoyl-sn-glycero-3-phosphate PA(36:1) & Avanti Polar Lipids & Cat\# 840861C \\
\hline 1-stearoyl-2-linoleoyl-sn-glycero-3-phosphate PA(36:2) & Avanti Polar Lipids & Cat\# 840862C \\
\hline $\begin{array}{l}\text { 1-stearoyl-2-docosahexaenoyl-sn-glycero-3-phosphate } \\
\text { PA(40:6) }\end{array}$ & Avanti Polar Lipids & Cat\# 840864C \\
\hline $\begin{array}{l}\text { 1,2-didocosahexaenoyl-sn-glycero-3-phosphate } \\
\text { PA(44:12) }\end{array}$ & Avanti Polar Lipids & Cat\# 840887C \\
\hline L- $\alpha$-phosphatidic acid (Egg, Chicken) PA mix & Avanti Polar Lipids & Cat\# 840101C \\
\hline Hexamethyldisilazane & Sigma Aldrich & Cat\# 440191 \\
\hline \multicolumn{3}{|l|}{ Critical Commercial Assays } \\
\hline 3-CAT research ELISA kit & Eurobio & BA E-5600 \\
\hline Basic Primary Neurons Nucleofector Kit & Lonza & VVPI-1003 \\
\hline \multicolumn{3}{|l|}{ Experimental Models: Cell Lines } \\
\hline $\mathrm{PC} 12$ & Laurent Taupenot & (Taupenot et al., 1998) \\
\hline \multicolumn{3}{|l|}{ Experimental Models: Organisms/Strains } \\
\hline Mouse Pld1 $1^{-1-}$ & Bernard Nieswandt & (Elvers et al., 2010) \\
\hline Mouse Pld2 ${ }^{-1-}$ & Gilbert Di Paolo & (Oliveira et al., 2010) \\
\hline \multicolumn{3}{|l|}{ Recombinant DNA } \\
\hline Spo20p-GFP & N/A & (Kassas et al., 2017) \\
\hline PDE4A1-GFP & N/A & (Kassas et al., 2017) \\
\hline \multicolumn{3}{|l|}{ Software and Algorithms } \\
\hline Adobe Photoshop & Adobe & https://www.adobe.com \\
\hline SigmaPlot 13 & Systat Software & https://systatsoftware.com \\
\hline Igor Pro & WaveMetrics & http://www.wavemetrics.com/ \\
\hline Macro for amperometry analysis & Ricardo Borges & http://rborges.webs.ull.es/ \\
\hline Icy & Biolmage Analysis Lab, Institut Pasteur & http://icy.bioimageanalysis.org/ \\
\hline \multicolumn{3}{|l|}{ Other } \\
\hline Carbon-fiber electrode of $5 \mu \mathrm{m}$ diameter & ALA Scientific & CFE-2 \\
\hline
\end{tabular}




\section{RESOURCE AVAILABILITY}

\section{Lead Contact}

Further information and requests for resources and reagents should be directed to and will be fulfilled by the lead contact, Nicolas Vitale, at vitalen@unistra.fr.

\section{Materials Availability}

This study did not generate new unique reagents.

Data and Code Availability

This study did not generate any unique datasets or code.

\section{EXPERIMENTAL MODEL AND SUBJECT DETAILS}

\section{Ethics Statement and Mouse Lines}

The Pld1 ${ }^{-1-}$ and $P l d 2^{-1-}$ mouse lines were described previously (Ammar et al., 2013, 2015). They were housed and raised at Chronobiotron UMS 3415. All experiments were carried out in accordance with the European Communities Council Directive of $24^{\text {th }}$ November 1986 (86/609/EEC) and resulting French regulations. Accordingly the CREMEAS local ethical committee approved all experimental protocols. Every effort was made to minimize the number of animals used and their suffering. 8 to 12-week-old males were sacrificed to recover adrenal glands and newborn mice were sacrificed to collect blood for catecholamine level measurements.

\section{Reagents}

FIPI, CAY93, CAY94 were dissolved in DMSO. Lipids were evaporated and suspended as micelles in Locke's solution by sonication. Controls always included the corresponding solvents.

\section{Primary Culture of Chromaffin and PC12 Cells}

Bovine chromaffin cells were isolated from fresh bovine adrenal glands by retrograde perfusion with collagenase, purified on selfgenerating Percoll gradients and maintained in culture as previously described (Vitale et al., 1993, 2001). Mouse adrenal glands were dissected and chromaffin cells purified from papain-digested medulla. Cells were seeded on collagen-coated coverslips and maintained at $37^{\circ} \mathrm{C}, 5 \% \mathrm{CO}_{2}$ for $24 \mathrm{~h}$ to 7 days before experiments as previously described (Houy et al., 2015). PC12 cells were cultured as described previously (Vitale et al., 2002). In brief, PC12 cells were grown in Dulbecco's modified Eagle's medium supplemented with glucose (4500 mg/liter) and containing $30 \mathrm{mM} \mathrm{NaHCO}_{3}, 5 \%$ fetal bovine serum, $10 \%$ horse serum, and $100 \mathrm{units} / \mathrm{mL}$ penicillin/streptomycin. To induce exocytosis, intact chromaffin and PC12 cells were washed twice with Locke's solution $(140 \mathrm{mM} \mathrm{NaCl}, 4.7 \mathrm{mM} \mathrm{KCl}$, $2.5 \mathrm{mM} \mathrm{CaCl}_{2}, 1.2 \mathrm{mM} \mathrm{KH}_{2} \mathrm{PO}_{4}, 1.2 \mathrm{mM} \mathrm{MgSO}_{4}, 11 \mathrm{mM}$ glucose, $0.56 \mathrm{mM}$ ascorbic acid, $0.01 \mathrm{mM}$ EDTA and $15 \mathrm{mM} \mathrm{HEPES}$, pH 7.5), and then stimulated with Locke's solution containing nicotine $(10 \mu \mathrm{M})$ or high $\mathrm{K}+$ depolarizing solution $\left(\mathrm{K}^{+} 59 \mathrm{mM}\right)$.

\section{METHOD DETAILS}

\section{Transfection}

PC12 cells were transfected at $50 \%-70 \%$ confluence with the indicated plasmids using Lipofectamine 2000 according to the manufacturer's protocol (Thermo Scientific) as described previously (Vitale et al., 2002). Bovine chromaffin cells were electroporated (Amaxa Nucleofactor systems, Lonza, Levallois, France) as described previously (Zeniou-Meyer et al., 2007).

\section{Amperometry}

Mouse or bovine chromaffin cells were washed with Locke's solution and processed for catecholamine release measurements by amperometry. Carbon-fiber electrode of $5 \mu \mathrm{m}$ diameter (ALA Scientific) was held at a potential of $+650 \mathrm{mV}$ compared with the reference electrode $(\mathrm{Ag} / \mathrm{AgCl})$ and approached closely to cells. Catecholamine's secretion was induced by $10 \mathrm{~s}$ pressure ejection of $100 \mathrm{mM} \mathrm{K}^{+}$or $100 \mu \mathrm{M}$ nicotine solution from a micropipette positioned at $10 \mu \mathrm{m}$ from the cell and recorded during $60 \mathrm{~s}$. Amperometric recordings were performed with an AMU130 (Radiometer Analytical) amplifier, sampled at $5 \mathrm{kHz}$, and digitally low-passed filtered at 1 kHz. Analysis of amperometric recordings was done as previously described (Gabel et al., 2015; Poëa-Guyon et al., 2013; ZeniouMeyer et al., 2007, 2008) with a macro (obtained from Dr. R. Borges laboratory; http://rborges. webs.ull.es/) written for lgor Pro software (WaveMetrics), allowing automatic spike detection and extraction of spike parameters. The number of amperometric spikes was counted as the total number of spikes with an amplitude $>5 \mathrm{pA}$ within $60 \mathrm{~s}$. The spike parameters analysis was restricted to spikes with amplitudes $>5 \mathrm{pA}$. Quantal size (spike charge) of individual spike is measured by calculating the spike area above the baseline. Spike area is defined as the time integral of each current transient, $I_{\max }$ the height of each peak, and half-width the width of each peak at half its height (Figure $2 \mathrm{C}$ ). All peaks identified by the program were visually inspected and overlapping peaks were manually excluded from the datasets. For foot signal, the analysis was restricted to spikes with foot amplitudes $>1.5 \mathrm{pA}$. Good practice for electrode calibration or criteria for electrode selection were performed according to Machado et al. (2008). 
Secretion and catecholamine ELISA assays

Bovine chromaffin cells maintained in 96-well plates (Thermo Fisher Scientific, France) were briefly washed twice with Locke and processed as stated in the figure legends. Aliquots of the medium were collected at the end of each experiment and cells were lysed with $1 \%(\mathrm{v} / \mathrm{v})$ Triton X-100 (Sigma, UK). Both sets of samples were assayed fluorometrically for catecholamine content as previously described (Gabel et al., 2019). Briefly, $20 \mu$ l of sample were transferred to 96-well black plates (Thermo Fisher Scientific, France), $150 \mu \mathrm{L}$ of $\mathrm{CH}_{3} \mathrm{COONa}\left(1 \mathrm{M}, \mathrm{pH}\right.$ ) and $15 \mu \mathrm{L}$ of $\mathrm{K}_{3} \mathrm{Fe}(\mathrm{CN})_{6}(0.25 \%)$ were added to each well to oxidize catecholamines to adrenochrome. Next $50 \mu \mathrm{l}$ of $\mathrm{NaOH}(5 \mathrm{M})$ containing ascorbic acid $(0.3 \mathrm{mg} / \mathrm{ml})$ were added, to convert adrenochrome to adrenolutin (Gabel et al., 2019). The fluorescence emitted by adrenolutin ( $\lambda_{\mathrm{ex}}: 430 \mathrm{~nm}, \lambda_{\mathrm{em}}: 520 \mathrm{~nm}$ ) is measured with a spectrofluorometer (LB940 Mithras, Berthold). For each experiment a standard curve was determined using known concentration of adrenaline and noradrenaline to demonstrate that the values obtained were in the linear range of detection of the assay. Amounts released were expressed as a percentage of the total amount of catecholamine present in the cells. Plotted data are representative of at least three independent experiments, each carried out in triplicate. For CgA secretion assay, bovine chromaffin cells were cultured in 24-wells plate for 48-72 $\mathrm{h}$ and then incubated for 60 min with the indicated PLD inhibitors, prior to stimulation in the presence or absence of the PLD inhibitors. $50 \mu \mathrm{L}$ supernatants were collected and added to $10 \mu \mathrm{L}$ of $10 \times$ Laemmli buffer. $15 \mu \mathrm{L}$ aliquots were run on $4 \%-12 \%$ Bis-Tris gel (NuPAGE) and CgA detected by western blot using an anti-CgA antibody at 1/5000 dilution followed by an anti-rabbitantibody conjugated to HRP at 1/50000 dilution and revealed as described previously (Tanguy et al., 2019b). Catecholamine levels from mice blood samples were measured using the 3-CAT research ELISA kit from LDN (Eurobio, Les Ulis, France) according to the manufacturer's instructions.

\section{Western blotting}

Bovine or mouse chromaffin cells, or PC12 cells grown in $1.2 \mathrm{~cm}$ diameter wells were harvested on ice by scraping in lysis buffer (10 mM Tris pH 7.4, $100 \mathrm{mM} \mathrm{NaCl}, 1 \mathrm{mM}$ EDTA, $1 \mathrm{mM}$ EGTA, $1 \mathrm{mM} \mathrm{NaF}, 20 \mathrm{mM} \mathrm{Na} \mathrm{P}_{2} \mathrm{O}_{7}, 2 \mathrm{mM} \mathrm{Na} \mathrm{VO}_{4}, 1 \% \mathrm{Triton} \mathrm{X}_{-100,10 \%}$ glycerol, $0.1 \%$ SDS, $0.5 \%$ deoxycholate and protease inhibitors). Protein extracts were analyzed on $4 \%-20 \%$ polyacrylamideSDS gels. Immunoblots were then revealed with anti-PLD1 at 1/500 dilution and anti-PLD2 at 1/200 dilution followed by an anti-rabbit antibody conjugated to HRP at 1/50000 dilution. Blots were processed using the Super Signal detection system (Pierce).

Subcellular fractionation and PA lipidomic analysis

$400 \times 10^{6}$ PC12 cells grown in 100-mm plates were washed twice with Locke's solution and then incubated for 10 min with Locke's solution (basal release) or stimulated with an elevated $\mathrm{K}^{+}$solution. Medium was removed and cells immediately scrapped in $1 \mathrm{~mL}$ of sucrose $0.32 \mathrm{M}(20 \mathrm{mM}$ Tris $\mathrm{pH}$ 8.0). Cells were broken and plasma and secretory granule membranes were collected in a Dounce homogenizer and centrifuged at $800 \times \mathrm{g}$ for $15 \mathrm{~min}$. The supernatant was further centrifuged at $20000 \times \mathrm{g}$ for $20 \mathrm{~min}$. The resulting supernatant was further centrifuged for $60 \mathrm{~min}$ at $100000 \mathrm{xg}$ to obtain the cytosol (supernatant) and microsomes (pellet enriched in endosomes). The $20000 \times$ g pellet containing the crude membrane fraction was resuspended in sucrose $0.32 \mathrm{M}(20 \mathrm{mM}$ Tris $\mathrm{pH} 8.0)$, layered on a cushion sucrose density gradient (sucrose 1-1.6 M, $20 \mathrm{mM}$ Tris $\mathrm{pH}$ 8.0) and centrifuged for $90 \mathrm{~min}$ at $100000 \times \mathrm{g}$ to separate the plasma membrane from secretory granules (Caumont et al., 2000). The upper fractions containing SNAP-25 (plasma membrane marker) and the pellet containing $\mathrm{CgA}$ (secretory granules marker) were collected and resuspended as described previously (Kassas et al., 2017; Vitale et al., 2002). Adrenal glands were dissected from wild-type, $P l d 1^{-1-}$ and $P l d 2^{-1-}$ mouse, weighted, cut into small peace and mixed in $200 \mu \mathrm{L}$ of sucrose $0.32 \mathrm{M}(20 \mathrm{mM}$ Tris- $\mathrm{HCl}, \mathrm{pH}$ 8.0). Total lipids from cell and tissue samples were extracted by the method of Bligh and Dyer (1959). Extracts were mixed with chloroform:methanol (4:1), vortexed for $10 \mathrm{~s}$ and left under agitation for $1 \mathrm{~h}$ at $4^{\circ} \mathrm{C}$. After a 5 min centrifugation at $13000 \mathrm{rpm}$, the organic phase $(150 \mu \mathrm{L})$ was recovered and analyzed by mass spectrometry (UPLC/MS/MS) on an Acquity UPLC system Waters corp. (Milford, USA) coupled to a Quattro Premier XE triple Quadrupole MS system Waters Micromass. The sample $(3 \mu \mathrm{L})$ was injected into an Acquity UPLC BEH HILIC Amide precolumn (2.1 $\mathrm{mm} \times 5 \mathrm{~mm}, 1.7 \mu \mathrm{m}$ particle size), coupled to a Waters Acquity UPLC BEH Amide column $(2.1 \mathrm{~mm} \times 100 \mathrm{~mm}, 1.7 \mu \mathrm{m}$ particle size) and maintained at $28^{\circ} \mathrm{C}$. The column was eluted with a mix of acetonitrile $99.5 \%$, ammonium hydroxide $0.5 \%$ (A) and acetonitrile $80 \%$, water $19.5 \%$, ammonium hydroxide $0.5 \%$ (B). The flow rate was $0.4 \mathrm{~mL} \cdot \mathrm{min}^{-1}$ using the following elution protocol: $93 \% \mathrm{~A}$ for 2 min, followed by the gradient, $93 \%$ A to $60 \%$ A in $1 \mathrm{~min}, 60 \%$ A to $50 \%$ A in $0.5 \mathrm{~min}, 50 \%$ A to $40 \%$ A in 1.5 min. The composition of the mobile phase was then returned to initial conditions as follows: $40 \%$ A to $50 \%$ A in 2 min, $50 \%$ A to $80 \%$ A in 2.5 min, $80 \%$ A to $93 \% \mathrm{~A}$ in $0.5 \mathrm{~min}$ and maintained in $93 \%$ A for $2 \mathrm{~min}$. UV spectra were recorded from 200 to $500 \mathrm{~nm}$. The system was run by MassLynx software (version 4.0). The ESI source was used in positive and negative mode with a capillary voltage $3.4 \mathrm{kV}$; RF lens at $0 \mathrm{~V}$, resolution (LM1, HM1, LM2, HM2) 15, ion energy 1 and 2:0.5. Source and desolvation temperatures were 135 and $400^{\circ} \mathrm{C}$. Flows rates of nitrogen for nebulizor and desolvation were 50 and 900 L.h ${ }^{-1}$. Pressure of the argon collision gas was $3.0 \times 10^{-3}$ mbar. Full-scan, Selected Ion Recording and Daughter Scan mode were used for qualitative analysis. Quantitative PA analysis were made based on MS/MS Multiple Reaction Monitoring (MRM) as described (Tabet et al., 2016). Briefly, MRM transitions for individual PAs were determined using PA standards (Avanti Polar Lipids, Alabaster, AL, USA). The PAs were identified as deprotonated parent ions [M- $\left.\mathrm{H}^{-}\right]$, cone energy was optimized for each PA and set to $44 \mathrm{~V}$. The predominant daughter fragment ions were then used for quantitative MRM analysis. After optimization, the collision energy was set to $44 \mathrm{~V}$. MRM transitions and specific retention times were used to selectively monitor PA. 
Transmission electron microscopy of chromaffin cells in situ and secretory granule docking analysis Wild-type, $P l d 1^{-1-}$ and $P l d 2^{-/-}$mice were anesthetized with a mixture of ketamine $(100 \mathrm{mg} / \mathrm{kg})$ and xylazine $(5 \mathrm{mg} / \mathrm{kg})$ and transcardiacally perfused with $0.1 \mathrm{M}$ phosphate buffer, $\mathrm{pH} 7.3$, containing $2 \%$ paraformaldehyde and $2.5 \%$ glutaraldehyde. The $2 \mathrm{~mm}$-thick slices were cut from the adrenal glands and postfixed in $1 \%$ glutaraldehyde in phosphate buffer overnight at $4{ }^{\circ} \mathrm{C}$. The slices were then immersed for $1 \mathrm{~h}$ in $\mathrm{OsO}_{4} 0.5 \%$ in phosphate buffer. $1 \mathrm{~mm}^{3-}$ blocks were cut in the adrenal medulla, dehydrated, and processed classically for embedding in Araldite and ultramicrotomy. Ultrathin sections were counterstained with uranyl acetate and examined with a Hitachi 7500 transmission electron microscope. Secretory granules were counted in 50 chromaffin cells from Wild-type, Pld $1^{-/-}$, and $P l d 2^{-I-}$ mice each with a visible nucleus randomly selected in ultrathin sections from several blocks (1 section/block) from each mouse. Granules were considered to be docked when being less than $50 \mathrm{~nm}$ from the plasma membrane.

Plasma membrane sheet preparation, immunolabeling and transmission electron microscopy

Cytoplasmic face-up membrane sheets were prepared and processed as previously described (Gabel et al., 2015). Cells expressing Spo20p-GFP or PDE4A1-GFP were used $<20 \mathrm{~h}$ after transfection. Carbon-coated Formvar films on nickel electron grids were spilled on unstimulated or $\mathrm{K}^{+}$-stimulated chromaffin cells. To prepare membrane sheets, a pressure was applied to the grids for $20 \mathrm{~s}$ then grids were lifted so that the fragments of the upper cell surface adhered to the grid. These fragments were fixed in $2 \%$ paraformaldehyde for $10 \mathrm{~min}$ at $4{ }^{\circ} \mathrm{C}$ immediately after cell stimulation and sheet preparation, which required less than $30 \mathrm{~s}$. After blocking in PBS with $1 \%$ BSA and $1 \%$ acetylated BSA, the immunolabeling was performed and revealed with $15 \mathrm{~nm}$ gold particles-conjugated secondary antibodies. These membrane sheets were fixed in $2.5 \%$ glutaraldehyde in PBS, postfixed with $0.5 \% \mathrm{OsO}_{4}$, dehydrated in a graded ethanol series, treated with hexamethyldisilazane (Sigma-Aldrich, St. Louis, MO, USA), air-dried and observed using a Hitachi 7500 transmission electron microscope. TEM images of plasma membrane sheets were randomly taken based on grid observation at lower magnification.

\section{Confocal microscopy}

For immunocytochemistry, chromaffin cells grown on fibronectin-coated glass coverslips were fixed and labeled as described previously (Chasserot-Golaz et al., 1996). Labeled cells were visualized using a Leica SP5Il confocal microscope. The amount of Spo20p-GFP labeling associated with the plasma membrane and nucleus were measured using ROI of equivalent size with ICY software and expressed as the ratio of fluorescence intensity at the plasma membrane and the nucleus.

\section{QUANTIFICATION AND STATISTICAL ANALYSIS}

\section{Data selection}

For amperometry recordings fields were randomly selected close to the center of the plates. To reduce variations due to electrodes cells from each condition were alternatively recorded every 2-3 cells.

For plasma membrane sheets, granules were counted on selected fields of $45 \mu \mathrm{m}^{2}$ and in blind conditions. Data are expressed as number of granules $/ \mu \mathrm{m}^{2}$. The number of granules and distances were determined manually using Adobe Photoshop.

\section{Statistical Analysis}

Data were analyzed using SigmaPlot 13 software. In the figure legends, $n$ represents the number of experiments or the number of cells analyzed as specified. Statistical significance has been assessed using t test or the Mann-Whitney test when data did not fulfill requirements for parametric tests, as indicated. 